\title{
Model-based evaluation of selenate and nitrate reduction in hydrogen-based membrane biofilm reactor
}

\author{
Chen, Xueming; Lai, Chun-Yu; Fang, Fang; Zhao, He-Ping; Dai, Xiaohu; Ni, Bing-Jie
}

Published in:

Chemical Engineering Science

Link to article, DOI:

10.1016/j.ces.2018.11.032

Publication date:

2019

Document Version

Peer reviewed version

Link back to DTU Orbit

Citation (APA):

Chen, X., Lai, C-Y., Fang, F., Zhao, H-P., Dai, X., \& Ni, B-J. (2019). Model-based evaluation of selenate and nitrate reduction in hydrogen-based membrane biofilm reactor. Chemical Engineering Science, 195, 262-270. https://doi.org/10.1016/j.ces.2018.11.032

\section{General rights}

Copyright and moral rights for the publications made accessible in the public portal are retained by the authors and/or other copyright owners and it is a condition of accessing publications that users recognise and abide by the legal requirements associated with these rights.

- Users may download and print one copy of any publication from the public portal for the purpose of private study or research.

- You may not further distribute the material or use it for any profit-making activity or commercial gain

- You may freely distribute the URL identifying the publication in the public portal 


\section{Accepted Manuscript}

Model-Based Evaluation of Selenate and Nitrate Reduction in Hydrogen-Based Membrane Biofilm Reactor

Xueming Chen, Chun-Yu Lai, Fang Fang, He-Ping Zhao, Xiaohu Dai, Bing-Jie $\mathrm{Ni}$

PII: S0009-2509(18)30809-1

DOI: https://doi.org/10.1016/j.ces.2018.11.032

Reference: CES 14620

To appear in: Chemical Engineering Science

Received Date: 30 May 2018

Revised Date: 29 October 2018

Accepted Date: 13 November 2018

Please cite this article as: X. Chen, C-Y. Lai, F. Fang, H-P. Zhao, X. Dai, B-J. Ni, Model-Based Evaluation of Selenate and Nitrate Reduction in Hydrogen-Based Membrane Biofilm Reactor, Chemical Engineering Science (2018), doi: https://doi.org/10.1016/j.ces.2018.11.032

This is a PDF file of an unedited manuscript that has been accepted for publication. As a service to our customers we are providing this early version of the manuscript. The manuscript will undergo copyediting, typesetting, and review of the resulting proof before it is published in its final form. Please note that during the production process errors may be discovered which could affect the content, and all legal disclaimers that apply to the journal pertain. 


\section{Model-Based Evaluation of Selenate and Nitrate Reduction in Hydrogen-Based Membrane Biofilm Reactor}

Xueming Chen ${ }^{1}$, Chun-Yu Lai ${ }^{2}$, Fang Fang ${ }^{3}$, He-Ping Zhao $^{2}$, Xiaohu Dai ${ }^{4}$, Bing-Jie Ni ${ }^{4}$,*

${ }^{1}$ Process and Systems Engineering Center (PROSYS), Department of Chemical and Biochemical Engineering, Technical University of Denmark, 2800 Kgs. Lyngby, Denmark

${ }^{2}$ Department of Environmental Engineering, College of Environmental and Resource Sciences, Zhejiang University, Hangzhou, China

${ }^{3}$ Key Laboratory of Integrated Regulation and Resource Development on Shallow Lakes, Ministry of Education, Hohai University, Nanjing 210098, China

${ }^{4}$ State Key Laboratory of Pollution Control and Resources Reuse, Shanghai institute of pollution control and ecological security, College of Environmental Science and Engineering, Tongji University, Shanghai 200092, China

\section{*Correspondence to}

Dr. Bing-Jie Ni, P: +86 21 65986849; F: +86 21 65983602; E-mail: bjni@tongji.edu.cn

\section{ABSTRACT}

A biofilm model was developed to describe the simultaneous $\mathrm{NO}_{3}{ }^{-}$and $\mathrm{SeO}_{4}{ }^{2-}$ reduction in a $\mathrm{H}_{2}$-based membrane biofilm reactor (MBfR). Model calibration and validation was conducted using the experimental data of a reported $\mathrm{H}_{2}$-based MBfR. With a good level of identifiability, the $\mathrm{SeO}_{4}{ }^{2-}$ affinity constant and the $\mathrm{SeO}_{3}{ }^{2-}$ affinity constant were estimated at $9.80 \pm 0.51 \mathrm{~g} \mathrm{Se}$ $\mathrm{m}^{-3}$ and $1.83 \pm 0.38 \mathrm{~g} \mathrm{Se}^{-3}$, respectively. The model was then applied to evaluate the effects of key operating conditions on the single-stage $\mathrm{H}_{2}$-based MBfR and the role of reactor configuration through comparing two-stage to single-stage MBfR systems. The results 
showed that i) high $\mathrm{SeO}_{4}{ }^{2-}$ or low $\mathrm{NO}_{3}{ }^{-}$concentration in the influent favored the growth of selenate-reducing bacteria (SeRB) and therefore benefited the Se removal, ii) the influent dissolved oxygen slightly inhibited the Se removal through enhancing the aerobic microbial respiration on $\mathrm{H}_{2}$, iii) the $\mathrm{H}_{2}$ supply should be controlled at a proper level to avoid SeRB suppression and $\mathrm{H}_{2}$ wastage, iv) thin biofilm should be avoided to ensure a protected niche for SeRB and therefore a promising Se removal, and v) the two-stage MBfR configuration offered relatively higher efficiency in removing $\mathrm{Se}$ and $\mathrm{NO}_{3}{ }^{-}$simultaneously under the same loading condition.

Keywords: Hydrogen-based membrane biofilm reactor; selenate; nitrate; mathematical modelling; model calibration

\section{INTRODUCTION}

Despite its role as an essential trace element for life, selenium (Se) can also pose severe threats on organisms. Selenium pollution of aquatic environment is a worldwide phenomenon and is mainly caused by a broad spectrum of human activities ranging from agricultural practices to industrial manufacturing operations (Lemly, 2002). Human intake of high concentrations of selenium produces definite toxic symptoms (WHO, 2011). Although the level of selenium in groundwater and surface water is typically below $1 \mathrm{~g} \mathrm{Se} \mathrm{m}^{-3}$ (WHO,

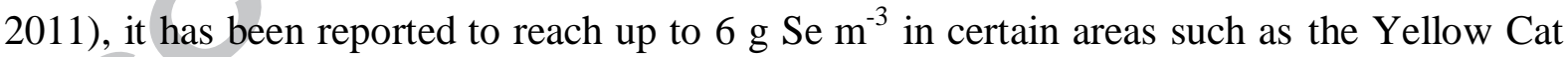
Area, Grand County, Utah (Cannon, 1964). To regulate the water quality for the sake of health and wellbeing, the US EPA has set the maximum contaminant level (MCL) of $0.05 \mathrm{~g}$ Se $\mathrm{m}^{-3}$ in drinking water (EPA, 2009) while the European Union and World Health Organization have recommended 0.01 and $0.04 \mathrm{~g} \mathrm{Se}^{-3}$, respectively, for drinking water. The US EPA has also set the effluent Se limit for the steam electric power generating sector at $12 \mathrm{mg} \mathrm{Se} \mathrm{m}^{-3}$ for existing sources and $5 \mathrm{mg} \mathrm{Se}^{-3}$ for new sources (EPA, 2015). 
The presence of selenium contamination is mainly in the form of oxyanions, such as selenate $\left(\mathrm{SeO}_{4}{ }^{2-}\right)$ and selenite $\left(\mathrm{SeO}_{3}{ }^{2-}\right)$. In contrast, the most reduced form of selenium, selenide $\left(\mathrm{Se}^{2-}\right)$, is rather unstable and can be readily oxidized to elemental selenium $\left(\mathrm{Se}^{0}\right)$, which is highly insoluble and of lower toxicity (Lai et al., 2014). Therefore, the common practice to remediate selenium-contaminated water is to reduce $\mathrm{SeO}_{4}{ }^{2-} / \mathrm{SeO}_{3}{ }^{2-}$ to $\mathrm{Se}^{0}$ which can then be recovered by filtration or centrifugation (Chung et al., 2006; Fellowes et al., 2011; Fesharaki et al., 2010). To achieve the reduction of $\mathrm{SeO}_{4}{ }^{2-} / \mathrm{SeO}_{3}{ }^{2-}$ to $\mathrm{Se}^{0}$, biological processes are usually preferred to physical-chemical techniques due to their adyantages in terms of adaptability to different wastewater types and treatment costs as well as their ability to work at low Se concentrations and efficiency in removing selenite (Chung et al., 2006); most physicalchemical methods have been documented to be suitable for selenite removal but less effective in removing selenate (Chung et al., 2006; Lee, 1989). Carbon-based reduction of selenate and selenite has been proposed (Cantafio et al., 1996; Gerhardt et al., 1991; Macy et al., 1993; Mal et al., 2017; Squires et al., 1989), however the use of organic carbon source as the electron donor typically necessitates post-treatment to get rid of excessive organic carbon addition to stabilize treated water.

Autotrophic reduction of selenate and selenite using inorganic electron donors such as hydrogen gas $\left(\mathrm{H}_{2}\right)$ represents a good alternative. $\mathrm{H}_{2}$ is not toxic to humans, and its low water solubility ensures negligible residual electron donor in the treated effluent. The membrane biofilm reactor (MBfR) is particularly suitable for delivery of $\mathrm{H}_{2}$ to microorganisms in spite of the explosive nature of $\mathrm{H}_{2}$ which necessitates proper measures to reduce the risk of explosions (Di Capua et al., 2015) and has been successfully applied to drive the respiratory reduction of selenate and selenite (Chung et al., 2006; Lai et al., 2014). In such a $\mathrm{H}_{2}$-based MBfR, $\mathrm{H}_{2}$ as the electron donor was supplied through gas-permeable bubbleless membranes, 
while $\mathrm{SeO}_{4}{ }^{2-}$ was provided in the bulk liquid and diffused into biofilm where $\mathrm{SeO}_{4}{ }^{2-}$ was subject to sequential reduction to $\mathrm{Se}^{0}$ via $\mathrm{SeO}_{3}{ }^{2-}$ by a group of selenate-reducing bacteria (SeRB).

Nevertheless, $\mathrm{SeO}_{4}{ }^{2-}$ reduction is significantly affected by the introduction of nitrate $\left(\mathrm{NO}_{3}{ }^{-}\right)$ in the $\mathrm{H}_{2}$-based MBfR. With the MCL of $10 \mathrm{~g} \mathrm{~N} \mathrm{~m}^{-3}$ in drinking water, nitrate is often concomitant in water contaminated by selenium (Zhang et al., 2003) and can induce methemoglobinemia in infants (Knobeloch et al., 2000). Chung et al. (2006) reported improved $\mathrm{SeO}_{4}{ }^{2-}$ reduction in the presence of a small amount of $\mathrm{NO}_{3}{ }^{-}$in the $\mathrm{MBfR}$ when $\mathrm{H}_{2}$ was not limiting. By comparison, another study by Lai et al. (2014) found that a high $\mathrm{NO}_{3}{ }^{-}$ loading would cause $\mathrm{H}_{2}$ limitation which suppressed $\mathrm{SeO}_{4}{ }^{2-}$ reduction. Different interactions between $\mathrm{SeO}_{4}{ }^{2-}$ and $\mathrm{NO}_{3}{ }^{-}$reduction are highly related to the microbial community structure in the biofilm. With the cooccurrence of $\mathrm{SeO}_{4}{ }^{2-}$ and $\mathrm{NO}_{3}{ }^{-}$as the electron acceptors in the $\mathrm{H}_{2-}$ based MBfR, microbial competitions arise between SeRB and denitrifying bacteria (DB) for the electron donor (i.e., $\mathrm{H}_{2}$ ). On top of the intrinsic differences in physiological and biochemical properties between microorganisms, the extent of microbial competitions and the resulting reduction performance are highly dependent on the operating conditions of the $\mathrm{H}_{2}$ based MBfR. So far, a number of uncertainties regarding the microbial competitions and the associated performance of the $\mathrm{H}_{2}$-based MBfR under different operating conditions remain undisclosed.

The aim of this work is therefore to investigate the impacts of operating conditions on the microbial community structure as well as the system performance of the $\mathrm{H}_{2}$-based MBfR treating $\mathrm{SeO}_{4}{ }^{2-}$ and $\mathrm{NO}_{3}{ }^{-}$simultaneously. To this end, a biofilm model integrating the key biological mechanisms mediating reduction of $\mathrm{SeO}_{4}{ }^{2-}, \mathrm{SeO}_{3}{ }^{2-}$ and $\mathrm{NO}_{3}{ }^{-}$as well as the 
potential aerobic growth of Se reducers (Lai et al., 2014) and $\mathrm{H}_{2}$-utilizing denitrifiers (Tang et al., 2012) in the $\mathrm{H}_{2}$-based MBfR was developed. The developed model was calibrated and validated using the long-term operating data collected from a single-stage $\mathrm{H}_{2}$-based $\mathrm{MBfR}$ reported in Lai et al. (2014), which was fed with different $\mathrm{NO}_{3}{ }^{-}$concentrations (i.e., $0,1.0$, 5.0 and $10.0 \mathrm{~g} \mathrm{~N} \mathrm{~m}^{-3}$ ) together with constant $\mathrm{SeO}_{4}{ }^{2-}$ and dissolved oxygen (DO) concentrations in the influent at different operating stages. The model was then applied to systematically quantify the effects of key operating factors including influent $\mathrm{SeO}_{4}{ }^{2-}, \mathrm{NO}_{3}{ }^{-}$ and DO concentrations, $\mathrm{H}_{2}$ loading and biofilm thickness on the system performance as well as the steady-state microbial community structure of the single-stage $\mathrm{H}_{2}$-based MBfR treating $\mathrm{SeO}_{4}{ }^{2-}$ and $\mathrm{NO}_{3}{ }^{-}$simultaneously. A brief comparison between two-stage (i.e., two MBfRs connected in series) and single-stage MBfR systems under same loading condition was also presented to shed light on the role of reactor configuration as an additional factor.

\section{MATERIALS AND METHODS}

\section{Model Development}

The multi-species process model was developed to describe both anoxic and aerobic mechanisms of SeRB, hydrogen-based autotrophic denitrifying bacteria (ADB) and heterotrophic bacteria (HB). In total, as detailed in Table S1 in the Supporting Information (SI), the model describes the relationships among seven dissolved components, i.e., hydrogen $\left(\mathrm{S}_{\mathrm{H} 2}\right)$, nitrate $\left(\mathrm{S}_{\mathrm{NO} 3}\right)$, selenate $\left(\mathrm{S}_{\mathrm{SeO} 4}\right)$, selenite $\left(\mathrm{S}_{\mathrm{SeO} 3}\right)$, dissolved oxygen $\left(\mathrm{S}_{\mathrm{O} 2}\right)$, utilizationassociated products (UAP, $\mathrm{S}_{\mathrm{UAP}}$ ) and biomass-associated products (BAP, $\mathrm{S}_{\mathrm{BAP}}$ ), and six particulate components, i.e., $\mathrm{ADB}\left(\mathrm{X}_{\mathrm{ADB}}\right), \mathrm{SeRB}\left(\mathrm{X}_{\mathrm{SeRB}}\right), \mathrm{HB}\left(\mathrm{X}_{\mathrm{HB}}\right)$, elemental selenium $\left(\mathrm{X}_{\mathrm{Se}}\right)$, inert organics $\left(\mathrm{X}_{\mathrm{I}}\right)$ and extracellular polymeric substances (EPS, $\left.\mathrm{X}_{\mathrm{EPS}}\right)$. In the model as presented in Table $1, \mathrm{H}_{2}$ serves as the electron donor and energy source driving the microbial reduction of $\mathrm{O}_{2}, \mathrm{SeO}_{4}{ }^{2-}, \mathrm{SeO}_{3}{ }^{2-}$ and $\mathrm{NO}_{3}{ }^{-}$. Electrons are fractionized based on mass balance 
for the synthesis of new biomass as well as the accompanying production of UAP and EPS. Biomass growth and UAP and EPS formation are linked to substrate consumption via yield coefficient (Y). EPS are hydrolyzed to BAP, which together with UAP are oxidized by HB to reduce $\mathrm{O}_{2}$ and $\mathrm{NO}_{3}{ }^{-}$. As listed in Table $\mathrm{S} 2$ in the SI, dual-substrate Monod equations were applied to describe the species-specific interactions between electron acceptors $\left(\mathrm{O}_{2}, \mathrm{SeO}_{4}{ }^{2-}\right.$, $\mathrm{SeO}_{3}{ }^{2-}$ and $\mathrm{NO}_{3}{ }^{-}$) and electron donors $\left(\mathrm{H}_{2}, \mathrm{UAP}\right.$ and BAP). As aerobic growth was included in addition to anoxic growth for all three microorganisms in the model, non-competitive oxygen inhibition functions were incorporated into the corresponding kinetic rate expressions. It should be noted that the intermediate $\mathrm{NO}_{2}^{-}$was not specifically included in the model considering its higher $\mathrm{H}_{2}$-utilization priority as well as the fact that it was not detected in related $\mathrm{H}_{2}$-based MBfR systems (Chen et al., 2017; Tang et al., 2013; Tang et al., 2012). The definitions, values, units and sources of all parameters used in the developed model are listed in Table S3 in the SI.

The one-dimensional biofilm model was then constructed on the software AQUASIM 2.1d (Reichert, 1998) to simulate the $\mathrm{H}_{2}$-based $\mathrm{MBfR}$ as a two-compartment structure: a completely mixed gas compartment representing the membrane lumen and a biofilm compartment containing the biofilm and bulk liquid. The $\mathrm{H}_{2}$ inflow in the gas compartment was determined by the applied gas pressure along with the gas flow rate. The $\mathrm{H}_{2}$ supply to the biofilm was simulated according to Henry's law and using a diffusive link, which connected the gas compartment to the base of the biofilm and modeled diffusive mass exchange of substances between compartments through membranes or boundary layers. Same with Terada et al. (2007), the boundary layer thickness was set at $100 \mu \mathrm{m}$, irrespective of biofilm thickness. The transport of dissolved components through the diffusion boundary layer and into or out of the biofilm was described with the resistance approach using Fick's first law. 
Diffusion coefficients for dissolved components in the biofilm liquid phase were set at 0.8 fold of the values in water. The specifications as well as the influent conditions in the model were set according to the operating conditions of experiments, the data of which were used for the subsequent model evaluation. More details related to the biofilm model setup can be found in Chen et al. (2017).

\section{Experimental Data}

Experimental data from the single-stage $\mathrm{H}_{2}$-based MBfR reported in (Lai et al., 2014) were used to calibrate and validate the developed model. The single-stage MBfR with a total volume of $65 \mathrm{~mL}$ contained a bundle of 32 composite hollow fiber membranes fixed at the bottom and another bundle of 10 coupon hollow fiber membranes in a separate tube which were used for microbial community analysis. The MBfR was initially inoculated with diluted activated sludge obtained from a wastewater treatment plant, and the microbial community was enriched by circulating $10 \mathrm{~g} \mathrm{~m}^{-3} \mathrm{SeO}_{4}{ }^{2-}$ for 48 hours. Upon the attainment of the enrichment as evidenced by the significant decrease in the bulk $\mathrm{SeO}_{4}{ }^{2-}$ concentration as well as the visually observed formation of biofilm outside the membrane surface, a medium containing $\mathrm{SeO}_{4}{ }^{2-}$ was fed to the $\mathrm{MBfR}$ and the concentration was maintained around $1 \mathrm{~g} \mathrm{Se}$ $\mathrm{m}^{-3}$ throughout the experiment. On top of $\mathrm{SeO}_{4}{ }^{2-}, \mathrm{NO}_{3}{ }^{-}$was also provided in the medium but at varied concentrations based on which the experiments were categorized into different operating stages: $0,10,0,1$ and $5 \mathrm{~g} \mathrm{~N} \mathrm{~m}^{-3}$ at Stages 1, 2, 3, 4 and 5, respectively. The next operating stage only commenced after the current operating stage reached steady state, which was indicated by stable effluent concentrations of all chemical indexes. The DO concentration in the influent was between 7.7 and $8.0 \mathrm{~g} \mathrm{~m}^{-3}$ for all stages. The liquid was completely mixed using a peristaltic pump at $100 \mathrm{~mL} \mathrm{~min}^{-1}$. The influent feeding was maintained at $0.5 \mathrm{~mL} \mathrm{~min}^{-1}$, the $\mathrm{H}_{2}$ pressure at $1.17 \mathrm{~atm}$, and the temperature at $25{ }^{\circ} \mathrm{C}$ for all 
stages. More details related to the system configuration, operation and analysis of the singlestage $\mathrm{H}_{2}$-based MBfR can be found in Lai et al. (2014).

\section{Model Calibration and Validation}

Slightly different from the framework proposed by Rittmann et al. (2018) that was in least favor of adjustments in kinetic and stoichiometric parameters, priority of this work was indeed placed in the tuning and determination of parameters associated with the anoxic processes of $\mathrm{H}_{2}$-based reduction of $\mathrm{SeO}_{4}{ }^{2-}$ and $\mathrm{SeO}_{3}{ }^{2-}$. This was in view of the fact that only parameters related to the anoxic mechanisms of $\mathrm{ADB}$ and $\mathrm{HB}$ and the aerobic bioconversion of $\mathrm{H}_{2}$ have been well established in the previous work (Chen et al., 2017). These parameter values were therefore directly adopted in this work. Of the remaining six parameters of interest, the yield in $\mathrm{H}_{2}$-based $\mathrm{SeO}_{4}{ }^{2-}$ reduction $\left(Y_{2}\right)$, the yield in $\mathrm{H}_{2}$-based $\mathrm{SeO}_{3}{ }^{2-}$ reduction $\left(Y_{3}\right)$, the maximum growth rate in $\mathrm{H}_{2}$-based $\mathrm{SeO}_{4}{ }^{2-}$ reduction $\left(\mu_{2}\right)$ and the maximum growth rate in $\mathrm{H}_{2}$-based $\mathrm{SeO}_{3}{ }^{2-}$ reduction $\left(\mu_{3}\right)$ were obtained at $0.13 \mathrm{~g} \mathrm{COD} \mathrm{g}^{-1} \mathrm{COD}, 0.11 \mathrm{~g} \mathrm{COD} \mathrm{g}^{-1}$ COD, $0.037 \mathrm{~h}^{-1}$ and $0.032 \mathrm{~h}^{-1}$, respectively, by thermodynamic state calculations assuming an energy-transfer efficiency of 0.6 (Kleerebezem and Van Loosdrecht, 2010). This approach as detailed in the SI has been well received and proved suitable for modelling similar $\mathrm{H}_{2}$-based MBfR systems (Chen et al., 2017; Tang et al., 2012). Hence, in the end, only the $\mathrm{SeO}_{4}{ }^{2-}$ affinity constant for $\mathrm{SeRB}\left(K_{\mathrm{SeO} 4}^{\mathrm{SeRB}}\right)$ and the $\mathrm{SeO}_{3}{ }^{2-}$ affinity constant for $\mathrm{SeRB}\left(K_{\mathrm{SeO} 3}^{\mathrm{SeRB}}\right)$ were evaluated using the long-term experimental data.

The experimental data collected during Stages 1, 2 and 3 of the single-stage $\mathrm{H}_{2}$-based MBfR system (Lai et al., 2014) were used for model calibration, which was conducted through minimizing the sum of squares of the deviations between the experimental measurements and the model predictions. Parameter estimation and uncertainty evaluation were conducted 
according to Batstone et al. (2003) with a 95\% confidence level for significance testing and parameter uncertainty analysis. A modified AQUASIM 2.1d was used to obtain the parameter confidence region (Ge et al., 2010). Model validation was performed with the calibrated model parameters using the experimental data obtained during Stages 4 and 5 of the singlestage $\mathrm{H}_{2}$-based MBfR system (Lai et al., 2014). With an initial value set at $1 \mu \mathrm{m}$ in the beginning of Stage 1, the thickness of biofilm, which was assumed to have a biomass density of $79300 \mathrm{~g} \mathrm{COD} \mathrm{m}^{-3}$ (Tang et al., 2012), was not specifically compared but was controlled with the limit of $100 \mu \mathrm{m}$ in the model evaluation process. The profiles of $\mathrm{SeO}_{4}{ }^{2-}, \mathrm{SeO}_{3}{ }^{2-}$ and $\mathrm{NO}_{3}{ }^{-}$were used simultaneously for the model calibration and validation processes. $\mathrm{Se}^{0}$ was not specifically considered in the model evaluation process because it was not measured experimentally.

\section{Assessment on Key Operating Factors}

The evaluated model was then applied to simulate the implementation of the $\mathrm{H}_{2}$-based MBfR treating $\mathrm{SeO}_{4}{ }^{2-}$ and $\mathrm{NO}_{3}$ simultaneously under different operating conditions. As shown in Table 2, six different scenarios are considered in total in this work. The first simulation scenario (i.e., Scenario 0 of Table 2) investigated the spatial distribution characteristics of the single-stage $\mathrm{H}_{2}$-based MBfR through generating depth-wise profiles of microbial community and substrates distribution in the biofilm. The $\mathrm{SeO}_{4}{ }^{2-}, \mathrm{NO}_{3}{ }^{-}$and $\mathrm{DO}$ concentrations for Scenario 0 were set at $1.0 \mathrm{~g} \mathrm{Se} \mathrm{m}^{-3}, 10.0 \mathrm{~g} \mathrm{~N} \mathrm{~m}^{-3}$ and $8.0 \mathrm{~g} \mathrm{~m}^{-3}$, respectively, which were comparable to Lai et al. (2014). $\mathrm{H}_{2}$ surface loading $\left(L_{\mathrm{H} 2}\right)$, influent surface loading $\left(L_{\mathrm{In}}\right)$ and biofilm thickness $\left(L_{\mathrm{f}}\right)$ were controlled at $0.128 \mathrm{~g} \mathrm{COD} \mathrm{m}^{-2} \mathrm{~h}^{-1}, 0.00236 \mathrm{~m} \mathrm{~h}^{-1}$ and $100 \mu \mathrm{m}$, respectively. As $\mathrm{SeO}_{4}{ }^{2-}, \mathrm{NO}_{3}{ }^{-}$and $\mathrm{DO}$ all act as electron acceptors, their varied concentrations in the real contaminated water would to great extent affect the $\mathrm{H}_{2}$-based MBfR. Therefore, Scenarios 1, 2 and 3 of Table 2 were designed to unveil the impacts of the influent $\mathrm{SeO}_{4}{ }^{2-}$, 
$\mathrm{NO}_{3}{ }^{-}$and DO concentrations, respectively, on the single-stage $\mathrm{H}_{2}$-based MBfR. The influent $\mathrm{SeO}_{4}{ }^{2-}$ concentration was varied from 0.1 to $5.0 \mathrm{~g} \mathrm{Se} \mathrm{m}^{-3}$ while the $\mathrm{NO}_{3}{ }^{-}$concentration was adjusted between 0.1 and $15.0 \mathrm{~g} \mathrm{~N} \mathrm{~m}^{-3}$. To account for all oxygenous conditions that might exist in reality, the DO concentration studied covered both anoxic condition (i.e., 0) to nearly saturated condition (i.e., $8.0 \mathrm{~g} \mathrm{~m}^{-3}$ ). Scenarios 4 and 5 of Table 2 explored the effects of $L_{\mathrm{H} 2}$ $\left(0.063-0.140 \mathrm{~g} \mathrm{COD} \mathrm{m}^{-2} \mathrm{~h}^{-1}\right)$ and $L_{\mathrm{f}}(40-180 \mu \mathrm{m})$, respectively, on the steady-state system performance and the related microbial community structure of the single-stage $\mathrm{H}_{2}$-based MBfR. Different $L_{\mathrm{f}}$ affected the quantity of biomass in the biofilm for different scenarios, which all assumed a biomass density of $79300 \mathrm{~g} \mathrm{COD} \mathrm{m}^{-3}$ (Tang et al., 2012). The last scenario (Scenario 6 of Table 2) compared two MBfR configurations: two-stage MBfR system (consisting of two $65 \mathrm{~mL}$ MBfRs which were connected in series) and one-stage MBfR system (consisting of one $65 \mathrm{~mL} \mathrm{MBfR}$ ). Despite the slight difference in the steadystate biofilm thickness setting as shown in Table 2, the two systems were subject to the same influent concentrations of $\mathrm{SeO}_{4}^{2-}, \mathrm{NO}_{3}^{-}$and $\mathrm{DO}$, the same influent surface loading and the same $\mathrm{H}_{2}$ supply.

The initial concentrations of all soluble components in the biofilm and the bulk liquid for each simulation scenario were assumed to be zero. An average biofilm thickness was applied in the model without consideration of its variation with locations. The steady-state biofilm thickness $\left(L_{\mathrm{f}}\right)$ was controlled by the surface detachment velocity equation $\left(u_{\mathrm{de}}\right)$ reported in $\mathrm{Ni}$ and Yuan (2013) as $u_{d e}=u_{F} \times\left(L_{f} / L_{f, \text { mean }}\right)^{2}$, where $u_{\mathrm{F}}$ represented the biofilm growth velocity while $L_{\mathrm{f} \text {,mean }}$ stood for the desired mean biofilm thickness. No re-attachment of detached particulates was considered in the model. All simulations assumed an initial biofilm thickness of $10 \mu \mathrm{m}$ and were run for up to 1000 days to reach steady-state conditions indicated by constant effluent concentrations, biofilm thickness and microbial compositions 
in biofilm. To systematically evaluate the MBfR's capacity of removing $\mathrm{SeO}_{4}{ }^{2-}$ and $\mathrm{SeO}_{3}{ }^{2-}$, the removal efficiency of soluble Se (referred to as Se removal efficiency hereinafter) was used in addition to the $\mathrm{NO}_{3}{ }^{-}$removal efficiency and the $\mathrm{H}_{2}$ utilization efficiency to represent the steady-state system performance.

\section{RESULTS AND DISCUSSION}

\section{Model Calibration and Validation}

$K_{\mathrm{SeO} 4}^{\mathrm{SeRB}}$ and $K_{\mathrm{SeO} 3}^{\mathrm{SeRB}}$ were estimated using the experimental data collected during Stages 1, 2 and 3 of the single-stage $\mathrm{H}_{2}$-based MBfR system, with the best fits obtained at $9.80 \mathrm{~g} \mathrm{Se} \mathrm{m}^{-3}$ and $1.83 \mathrm{~g} \mathrm{Se} \mathrm{m}^{-3}$, respectively. Figure 1A illustrates the model calibration results including the predicted and measured dynamic profiles of $\mathrm{SeO}_{4}{ }^{2-}, \mathrm{SeO}_{3}{ }^{2-}$ and $\mathrm{NO}_{3}{ }^{-}$in the influent and effluent fluxes, while Figure $1 \mathrm{~B}$ directly compares the predicted and measured $\mathrm{Se}$ and $\mathrm{NO}_{3}{ }^{-}$ removal efficiencies. During Stage 1 (days $1-67$ ) when $\mathrm{SeO}_{4}{ }^{2-}$ was the only input electron acceptor, $\mathrm{SeO}_{4}{ }^{2-}$ was reduced to $\mathrm{SeO}_{3}{ }^{2-}$, which was further reduced to $\mathrm{Se}^{0}$. With the influent $\mathrm{SeO}_{4}{ }^{2-}$ maintained around $1.0 \mathrm{~g} \mathrm{Se} \mathrm{m}^{-3}$, the effluent $\mathrm{SeO}_{4}{ }^{2-}$ concentration gradually decreased, resulting from the increased biomass and hence enhanced reduction capacity of SeRB in the biofilm. $\mathrm{SeO}_{3}{ }^{2-}$ accumulated in the $\mathrm{MBfR}$ due to the higher rate of $\mathrm{SeO}_{4}{ }^{2-}$ reduction than $\mathrm{SeO}_{3}{ }^{2-}$ reduction (Lai et al., 2014). As the difference between $\mathrm{SeO}_{4}{ }^{2-}$ removed and $\mathrm{SeO}_{3}{ }^{2-}$ produced represented the total Se removed, the Se removal of the MBfR increased slightly with time. At Stage 2 (days 67 - 106), the introduction of about $10.0 \mathrm{~g} \mathrm{NO}_{3}^{-}-\mathrm{N} \mathrm{m}^{-3}$ to the MBfR suppressed the Se removal through microbial competitions for the electron donor (i.e., $\mathrm{H}_{2}$ ). As a result, the effluent $\mathrm{SeO}_{4}{ }^{2-}$ increased significantly. In contrast, around $80 \%$ of the feeding $\mathrm{NO}_{3}{ }^{-}$was removed in the $\mathrm{MBfR}$, leading to the steady effluent $\mathrm{NO}_{3}{ }^{-}$concentration of about $2.0 \mathrm{~g} \mathrm{~N} \mathrm{~m}^{-3}$. When the feeding $\mathrm{NO}_{3}{ }^{-}$was removed at Stage 3 (days $106-138$ ), $\mathrm{SeO}_{4}{ }^{2-}$ reduction recovered. The noted discrepancies between the model predicted and 
experimentally measured effluent $\mathrm{SeO}_{4}{ }^{2-}$ levels and $\mathrm{Se}$ removal efficiencies at Stages 2 and 3 in Figure 1 could be ascribed to the possible overlook of i) the capability of some SeRB to degrade nitrate (Lai et al., 2014) or ii) the impact of the changing influent composition on the biofilm structure in the model of this work. Nevertheless, as evidenced by the acceptably high correlation (0.59) between model predicted and experimentally measured profiles of effluent Se oxyanions (i.e., $\mathrm{SeO}_{4}{ }^{2-}+\mathrm{SeO}_{3}{ }^{2-}$ ) as well as the comparable levels of model predicted and experimentally measured effluent Se oxyanions $\left(0.84 \pm 0.23 \mathrm{~g} \mathrm{Se} \mathrm{m}^{-3}\right.$ versus $0.89 \pm 0.26 \mathrm{~g} \mathrm{Se}$ $\left.\mathrm{m}^{-3}\right)$ and $\mathrm{NO}_{3}{ }^{-}\left(1.63 \pm 0.02 \mathrm{~g} \mathrm{NO}_{3}^{-}-\mathrm{N} \mathrm{m}^{-3}\right.$ versus $\left.1.87 \pm 0.38 \mathrm{~g} \mathrm{NO}_{3}^{-}-\mathrm{N} \mathrm{m}^{-3}\right)$, the model was able to capture the general variation trends of $\mathrm{SeO}_{4}{ }^{2-}, \mathrm{SeO}_{3}{ }^{2-}$ and $\mathrm{NO}_{3}{ }^{-}$to a satisfactory extent, which supported the validity of the calibrated model.

The $95 \%$ confidence region for $K_{S e O 4}^{S e R B}$ and $K_{S e O 3}^{S e R B}$ in combination with their uncorrelated confidence intervals obtained during the model calibration process is delineated in Figure S1 in the SI. The uncorrelated confidence intervals of both parameters were relatively small and fully covered by the correlated confidence region, indicating a good level of reliability and identifiability of the estimated values.

Model validation was conducted by comparing the experimental data at Stages 4 and 5 with the model predictions obtained using the calibrated model, the results of which are shown in Figure 2. At Stage 4 (days $138-183$ ), the reappearance of $1.0 \mathrm{~g} \mathrm{NO}_{3}{ }^{-}-\mathrm{N} \mathrm{m}^{-3}$ in the influent of the MBfR didn't significantly affect the Se removal. With the influent $\mathrm{SeO}_{4}{ }^{2-}$ concentration of about $1.3 \mathrm{~g} \mathrm{Se} \mathrm{m}^{-3}$, the effluent $\mathrm{SeO}_{4}{ }^{2-}$ and $\mathrm{SeO}_{3}{ }^{2-}$ concentrations fluctuated but stayed relatively stable $\left(0.4-0.5 \mathrm{~g} \mathrm{Se}^{-3}\right.$ and $0.1-0.2 \mathrm{~g} \mathrm{Se} \mathrm{m}^{-3}$, respectively). In the meanwhile, the influent $\mathrm{NO}_{3}{ }^{-}$was completely removed, leaving trace amount in the effluent. Further increase in the influent $\mathrm{NO}_{3}{ }^{-}$concentration to $5.0 \mathrm{~g} \mathrm{~N} \mathrm{~m}^{-3}$ at Stage 5 brought insignificant 
changes to the Se removal, which was in the form of $\mathrm{Se}^{0}$ and was proved by the visual observation of reddish-brown color in the MBfR. The good match between the model predicted and measured trends, supported by the satisfactory correlation between model predictions and experimental measurements for effluent Se oxyanions (0.69) and $\mathrm{NO}_{3}{ }^{-}(0.56)$ as well as their comparable concentration levels and removal efficiencies as shown in Figure 2, further verified the validity of the developed model.

\section{Characteristics of the $\mathrm{H}_{2}$-Based MBfR Biofilm}

Scenario 0 of Table 2 investigated the spatial distribution characteristics of the biofilm which reflected the acting mechanisms behind the system performance of the single-stage $\mathrm{H}_{2}$-based MBfR treating $\mathrm{SeO}_{4}{ }^{2-}$ and $\mathrm{NO}_{3}{ }^{-}$simultaneously. With $99.9 \%$ of the $\mathrm{H}_{2}$ supplied being utilized as electron donor, the steady-state $\mathrm{Se}$ and $\mathrm{NO}_{3}{ }^{-}$removal efficiencies were $40.5 \%$ and $95.7 \%$, respectively. The steady-state distribution profiles of solid and dissolved species in the biofilm under the operating conditions of Scenario 0 are shown in Figure 3. As shown in Figure $3 \mathrm{~A}, \mathrm{SeRB}$ were most abundant $(6 \%)$ at the base of the biofilm where $\mathrm{H}_{2}$ was supplied. In contrast, $\mathrm{HB}$, the abundance of which was independent of $\mathrm{H}_{2}$ supply, were densest (12\%) at the biofilm surface. ADB were the most dominant microbial species, with an abundance of over $40 \%$ across the biofilm. Considering the counter diffusion of $\mathrm{H}_{2}$ and $\mathrm{NO}_{3}{ }^{-}$as the substrates for ADB from the two sides of the biofilm, the abundance of ADB reached the peak $(55 \%)$ in the middle of the biofilm (See Figure 3A). Inert biomass was higher on the membrane side and decreased significantly towards the bulk liquid, which was in contrast with a similar $\mathrm{H}_{2}$-based $\mathrm{MBfR}$ system fed with $\mathrm{NO}_{3}{ }^{-}$and $\mathrm{ClO}_{4}{ }^{-}$(Tang et al., 2012) as well as another $\mathrm{H}_{2}$-based MBfR system treating $\mathrm{NO}_{3}{ }^{-}$and $\mathrm{SO}_{4}{ }^{2-}$ (Tang et al., 2013). More active biomass was therefore present at the biofilm surface, hence the higher fraction of EPS on the 
bulk liquid side. Despite the different trend observed, the overall fraction of EPS in the biofilm was still comparable with Tang et al. (2012) and Tang et al. (2013).

Figure 3B demonstrates the associated profiles of dissolved species within the biofilm of Scenario $0 . \mathrm{H}_{2}$ decreased from the membrane surface where it was supplied towards the bulk liquid. On the contrary, the $\mathrm{SeO}_{4}{ }^{2-}$ and $\mathrm{NO}_{3}{ }^{-}$concentrations both decreased from the bulk liquid where they were provided to the base of the biofilm. The $\mathrm{SeO}_{3}{ }^{2-}$ concentration almost remained unchanged across the biofilm thickness. UAP and BAP were produced in the biofilm and then diffused into the liquid, therefore, their concentrations were higher in the inner layer of the biofilm. The DO supplied in the influent was quickly consumed within the top biofilm layer, creating a nearly anoxic environment in the biofilm under the simulation conditions of Scenario 0 .

As presented in Figure 3, the counter-diffusional supply of gas and liquid substrates resulted in the stratification in the biofilm, which determined the system performance of the singlestage $\mathrm{H}_{2}$-based MBfR. This heterogeneous, stratified characteristic of biofilm has been shown to vary among systems and be controlled by operating conditions (Chen et al., 2017; Tang et al., 2013; Tang et al., 2012). Therefore, a systematic study on the impacts of key operating factors should be conducted to comprehensively evaluate the feasibility of applying the $\mathrm{H}_{2}$ based MBfR technology to treat $\mathrm{SeO}_{4}{ }^{2-}$ and $\mathrm{NO}_{3}{ }^{-}$simultaneously.

\section{Key Operating Factors Affecting the Single-Stage $\mathrm{H}_{2}$-Based MBfR}

The impact of the influent $\mathrm{SeO}_{4}{ }^{2-}$ concentration on the steady-state system performance and microbial community structure of the single-stage $\mathrm{H}_{2}$-based MBfR (Scenario 1 of Table 2) is shown in Figure 4A. There was no $\mathrm{SeO}_{4}{ }^{2-}$ reduction and hence no Se removal when the 
influent $\mathrm{SeO}_{4}{ }^{2-}$ concentration was less than $0.75 \mathrm{~g} \mathrm{Se} \mathrm{m}^{-3}$. The $\mathrm{H}_{2}$ supply was solely used for $\mathrm{NO}_{3}{ }^{-}$reduction, thus rendering the $\mathrm{NO}_{3}{ }^{-}$removal efficiency of $95.8 \%$ and the $\mathrm{H}_{2}$ utilisation efficiency of $99.8 \% . \mathrm{SeO}_{4}{ }^{2-}$ reduction arose with the Se removal efficiency of $23.4 \%$ at the influent $\mathrm{SeO}_{4}{ }^{2-}$ concentration of $0.75 \mathrm{~g} \mathrm{Se} \mathrm{m}^{-3}$. Further increase in the influent $\mathrm{SeO}_{4}{ }^{2-}$ concentration led to consistently increased Se removal efficiency, reaching $68.6 \%$ at the highest influent $\mathrm{SeO}_{4}{ }^{2-}$ concentration of $5 \mathrm{~g} \mathrm{Se} \mathrm{m}^{-3}$ studied in this work. The corresponding $\mathrm{NO}_{3}{ }^{-}$removal efficiency slightly decreased to $94.7 \%$ while the complete $\mathrm{H}_{2}$ utilisation $(100 \%)$ was achieved. The varying system performance was attributed to the changing microbial community structure in the biofilm under different influent $\mathrm{SeO}_{4}{ }^{2-}$ concentration conditions, as delineated in Figure 4A. A low influent $\mathrm{SeO}_{4}{ }^{2-}$ concentration of below $0.75 \mathrm{~g} \mathrm{Se} \mathrm{m}^{-3}$ led to the washout of SeRB from the biofilm. As a result, ADB and HB dominated the biofilm, each accounting for $93 \%$ and $7 \%$ of the active biomass. With the increasing influent $\mathrm{SeO}_{4}{ }^{2-}$ concentration, SeRB started to gain advantage in competing with ADB for $\mathrm{H}_{2}$. Consequently, SeRB $(2 \%)$ appeared in the biofilm at the influent $\mathrm{SeO}_{4}{ }^{2-}$ concentration of $0.75 \mathrm{~g} \mathrm{Se} \mathrm{m}^{-3}$. Thereafter, the active fraction of SeRB increased while that of ADB decreased. The decreased active fraction of $\mathrm{ADB}$ benefited the growth of $\mathrm{HB}$ which competed with $\mathrm{ADB}$ for $\mathrm{NO}_{3}{ }^{-}$, thus leading to the increased active fraction of $\mathrm{HB}$ in the biofilm. Therefore, at the influent $\mathrm{SeO}_{4}{ }^{2-}$ concentration of $5 \mathrm{~g} \mathrm{Se} \mathrm{m}^{-3}, \mathrm{SeRB}, \mathrm{ADB}$ and $\mathrm{HB}$ coexisted in the biofilm, each taking up $11 \%, 77 \%$ and $12 \%$ of the total active biomass, respectively.

The relationship between the influent $\mathrm{NO}_{3}{ }^{-}$concentration and the steady-state system performance as well as microbial community structure of the single-stage $\mathrm{H}_{2}$-based MBfR (Scenario 2 of Table 2) is shown in Figure 4B. When the influent $\mathrm{NO}_{3}{ }^{-}$concentration was lower than $1.0 \mathrm{~g} \mathrm{~N} \mathrm{~m}^{-3}$, $\mathrm{HB}$ were outcompeted by $\mathrm{ADB}$, resulting in the joint dominance of $\mathrm{ADB}$ and $\mathrm{SeRB}$ in the biofilm. However, with the increased $\mathrm{NO}_{3}{ }^{-}$concentration in the 
influent, the abundance of ADB increased while that of SeRB decreased, hence the decreased Se removal efficiency. The excessive $\mathrm{H}_{2}$ supply at relatively low influent $\mathrm{NO}_{3}{ }^{-}$concentration led to stable and high-level $\mathrm{NO}_{3}{ }^{-}$removal ( 95.0\%), and the $\mathrm{H}_{2}$ utilisation efficiency increased with the increased influent $\mathrm{NO}_{3}{ }^{-}$concentration. At the influent $\mathrm{NO}_{3}{ }^{-}$concentration of $2.5 \mathrm{~g} \mathrm{~N} \mathrm{~m}^{-3}$, HB appeared in the biofilm with the abundance of $3 \%$ while ADB and SeRB each accounted for $89 \%$ and $8 \%$ of the active biomass. The corresponding $\mathrm{NO}_{3}{ }^{-}$removal efficiency, Se removal efficiency and $\mathrm{H}_{2}$ utilisation efficiency were $95.7 \%, 53.2 \%$ and $77.8 \%$, respectively. Further increase in the influent $\mathrm{NO}_{3}{ }^{-}$concentration induced more $\mathrm{HB}$, which negatively affected the existence of SeRB in the biofilm and hence the Se removal efficiency. When the influent $\mathrm{NO}_{3}{ }^{-}$concentration reached over $10.0 \mathrm{~g} \mathrm{~N} \mathrm{~m}^{-3}, \mathrm{H}_{2}$ supply became limited, indicated by the $100 \% \mathrm{H}_{2}$ utilisation efficiency and the decreased $\mathrm{NO}_{3}{ }^{-}$removal efficiency. Consequently, SeRB were completely washed out of biofilm and ADB (90\%) and HB (10\%) dominated the biofilm. In that case, no Se removal was observed in the MBfR.

The role of the influent DO concentration on the steady-state microbial community structure and system performance of the single-stage $\mathrm{H}_{2}$-based MBfR (Scenario 3 of Table 2) is depicted in Figure 4C. When there was no DO in the influent, SeRB, ADB and HB coexisted in the biofilm, each occupying $4 \%, 89 \%$ and $7 \%$ of the active biomass. The resulting $\mathrm{NO}_{3}{ }^{-}$ removal efficiency, Se removal efficiency and $\mathrm{H}_{2}$ utilisation efficiency were $96.0 \%, 44.6 \%$ and $94.6 \%$, respectively. The increase in the influent DO concentration slightly decreased the active biomass fraction of SeRB, which reached $3 \%$ at the maximum DO concentration of 8.0 $\mathrm{g} \mathrm{m}^{-3}$ studied in this work. Consequently, the Se removal efficiency decreased gradually to $40.5 \%$. The increased introduction of DO also enhanced the aerobic microbial respiration on $\mathrm{H}_{2}$, hence the increased $\mathrm{H}_{2}$ utilisation efficiency which reached $99.9 \%$ at the maximum DO concentration of $8.0 \mathrm{~g} \mathrm{~m}^{-3}$. No significant change was observed for the $\mathrm{NO}_{3}^{-}$removal 
efficiency which remained around $96.0 \%$, due to the almost unchanged active biomass fraction of $\mathrm{ADB}$ in the biofilm.

The dependence of the steady-state microbial community structure and system performance of the single-stage $\mathrm{H}_{2}$-based $\mathrm{MBfR}$ on the $\mathrm{H}_{2}$ loading $\left(L_{\mathrm{H} 2}\right)$ (Scenario 4 of Table 2) is depicted in Figure 4D. When $L_{\mathrm{H} 2}$ was relatively low $\left(<0.115 \mathrm{~g} \mathrm{COD} \mathrm{m}^{-2} \mathrm{~h}^{-2}\right)$, ADB $(90 \%)$ dominated the biofilm with the coexistence of a low fraction of $\mathrm{HB}(10 \%)$, due to their competitive advantage over SeRB for $\mathrm{H}_{2}$. The $\mathrm{H}_{2}$ supplied was completely consumed. As a result, there was no Se removal while the $\mathrm{NO}_{3}{ }^{-}$removal efficiency kept increasing from $39.5 \%$ at $L_{\mathrm{H} 2}$ of $0.063 \mathrm{~g} \mathrm{COD} \mathrm{m} \mathrm{m}^{-2}$. The increase of $L_{\mathrm{H} 2}$ to $0.125 \mathrm{~g} \mathrm{COD} \mathrm{m}^{-2} \mathrm{~h}^{-2}$ increased the availability of $\mathrm{H}_{2}$ for SeRB. Consequently, SeRB (1\%) appeared and coexisted with ADB $(91 \%)$ and $\mathrm{HB}(8 \%)$ in the biofilm, rendering the $\mathrm{Se}$ and $\mathrm{NO}_{3}{ }^{-}$removal efficiencies of $20.1 \%$ and $94.9 \%$, respectively, at $L_{\mathrm{H} 2}$ of $0.125 \mathrm{~g} \mathrm{COD} \mathrm{m}^{-2} \mathrm{~h}^{-2}$. Further increase in $L_{\mathrm{H} 2}$ to $0.128 \mathrm{~g}$ COD $\mathrm{m}^{-2} \mathrm{~h}^{-2}$ stimulated the growth and enhanced the fraction of SeRB but slightly depressed that of $\mathrm{ADB}$, giving rise to the increased Se removal efficiency of $40.5 \%$. However, excessive $\mathrm{H}_{2}$ supply of over $0.132 \mathrm{~g} \mathrm{COD} \mathrm{m}^{-2} \mathrm{~h}^{-2}$ did not make further significant change to the microbial community structure, with SeRB, ADB and HB taking up 4\%, $89 \%$ and $7 \%$ of the total active biomass, respectively. The resulting $\mathrm{Se}$ and $\mathrm{NO}_{3}{ }^{-}$removal efficiencies maintained at $44.2 \%$ and $95.9 \%$, respectively. The accompanying $\mathrm{H}_{2}$ utilization efficiency dropped consistently from $100 \%$ to $91.5 \%$ at $L_{\mathrm{H} 2}$ of $0.140 \mathrm{~g} \mathrm{COD} \mathrm{m}^{-2} \mathrm{~h}^{-2}$.

The sensitivity of the steady-state system performance and microbial community structure of the single-stage $\mathrm{H}_{2}$-based MBfR to the biofilm thickness $\left(L_{\mathrm{f}}\right)$ (Scenario 5 of Table 2) is illustrated in Figure 4E. Due to the loss in the competition for $\mathrm{H}_{2}$, SeRB were absent from the biofilm at $L_{\mathrm{f}}$ of $<80 \mu \mathrm{m}$, hence zero Se removal in the system. However, the Se removal 
efficiency quickly increased to $40.5 \%$ at $L_{\mathrm{f}}$ of $100 \mu \mathrm{m}$ due to the appearance of SeRB (3\%) in the biofilm. Further increase in $L_{\mathrm{f}}$ slightly favored the growth of SeRB but their abundance was confined to $4 \%$ due to the finite $\mathrm{H}_{2}$ supply, as evidenced by the complete $(100 \%) \mathrm{H}_{2}$ utilization. Therefore, the maximum Se removal efficiency was limited to around $50 \%$ (See Figure 4E). The $\mathrm{NO}_{3}{ }^{-}$removal efficiency was not significantly impacted by the enhanced abundance of SeRB in the thicker biofilm but remained high $(94.2 \%)$ at the maximum $L_{\mathrm{f}}$ of $180 \mu \mathrm{m}$ studied in this work.

Overall, the single-stage $\mathrm{H}_{2}$-based MBfR was particularly suitable for treating wastewater with high-level $\mathrm{SeO}_{4}{ }^{2-}$ (e.g., $>2 \mathrm{~g} \mathrm{Se} \mathrm{m}^{-3}$ ) but low-level $\mathrm{NO}_{3}{ }^{-}$(e.g., $<5 \mathrm{~g} \mathrm{~N} \mathrm{~m}^{-3}$ ) (i.e., a relatively high influent $\mathrm{SeO}_{4}{ }^{2-} / \mathrm{NO}_{3}{ }^{-}$ratio) which favored the anoxic growth of $\mathrm{SeRB}$ on $\mathrm{H}_{2}$ in the presence of $\mathrm{ADB}$ and $\mathrm{HB}$ (Figures $4 \mathrm{~A}$ and $4 \mathrm{~B}$ ). The influent DO slightly affected the Se removal through enhancing the aerobic microbial respiration on $\mathrm{H}_{2}$ (Figure 4C). When operating such a single-stage $\mathrm{H}_{2}$-based MBfR, the $\mathrm{H}_{2}$ supply should be controlled carefully. As shown in Figure 4D, a too low $L_{\mathrm{H} 2}$ would suppress the proliferation of $\mathrm{SeRB}$ in the biofilm and thus compromise the Se removal, while a too high $L_{\mathrm{H} 2}$ would bring about energy wastage. Moreover, a thin biofilm which would fail in providing a protected niche for SeRB (Figure 4E) should be avoided. This work doesn't focus on the process optimization of the $\mathrm{H}_{2}$-based MBfR in consideration of various operating conditions, but it is feasible via modeling and warrants further work. From Figure 4 it seems that high-level (e.g., >90\%) Se removal is hard to achieve only with the single-stage $\mathrm{H}_{2}$-based MBfR unless the influent concomitant $\mathrm{NO}_{3}{ }^{-}$concentration is extremely low. Therefore, downstream refining process (such as those aforementioned physical-chemical methods) should be included to meet the direct discharge limit of $0.05 \mathrm{~g} \mathrm{Se}^{-3}$. 


\section{Comparison between Single-Stage and Two-Stage MBfR Systems}

Figure 5 compares the two-stage and single-stage MBfR systems under the same loading condition set in Scenario 6 of Table 2. As shown in Figure 5A, different microbial compositions were observed in the two MBfRs of the two-stage system: ADB (89\%), SeRB (3\%) and HB (8\%) were present in the first-stage MBfR while ADB (89\%) and SeRB (11\%) dominated the biofilm of the second-stage MBfR without HB. The reason for the different microbial community structure lied in the different influent compositions for the two MBfRs. According to Figure 5B, around $40.5 \%$ of Se removal and $95.7 \%$ of $\mathrm{NO}_{3}{ }^{-}$removal were achieved in the first-stage MBfR. The high-level $\mathrm{NO}_{3}{ }^{-}$removal in the first-stage MBfR gave rise to a low $\mathrm{NO}_{3}{ }^{-}$(compared to $\mathrm{SeO}_{4}{ }^{2-}$ ) concentration in the influent for the second-stage MBfR. The low influent $\mathrm{NO}_{3}{ }^{-}$concentration condition favored the growth of ADB over $\mathrm{HB}$ and therefore washed HB out of the biofilm in the long term, analogous to the low influent $\mathrm{NO}_{3}{ }^{-}$case in Scenario 2 (See Figure 4B). The higher abundance of SeRB in the second-stage MBfR contributed to $34.6 \%$ of Se removal while the $\mathrm{NO}_{3}{ }^{-}$removal was further enhanced with $96.9 \%$ removal efficiency (Figure 5B). Overall, as indicated in Figure 5C, the two-stage MBfR system rendered the $\mathrm{Se}$ and $\mathrm{NO}_{3}{ }^{-}$removal efficiencies of $61.1 \%$ and $99.9 \%$, respectively, around $5 \%$ and $2 \%$ higher than those of the single-stage counterpart under the same loading condition.

The same $\mathrm{H}_{2}$ utilisation efficiency of $83.5 \%$ for the two systems suggested that the two-stage MBfR configuration was more efficient in removing $\mathrm{Se}$ and $\mathrm{NO}_{3}{ }^{-}$simultaneously. Despite other benefits such as better control flexibility, the two-stage MBfR system might necessitate higher construction and operation cost which affects it applicability. The trade-off is highly case-specific and therefore warrants further research. In fact, the two-stage $\mathrm{H}_{2}$-based MBfR system has been tested in the lab by Zhao et al. (2013) aiming to remove $\mathrm{NO}_{3}{ }^{-}$and 
perchlorate $\left(\mathrm{ClO}_{4}{ }^{-}\right)$while retaining sulfate $\left(\mathrm{SO}_{4}{ }^{2-}\right)$. Despite the agreement that $\mathrm{NO}_{3}{ }^{-}$was mainly removed in the first-stage MBfR, this work differed from Zhao et al. (2013) in terms of the efficacy of the second-stage MBfR. Zhao et al. (2013) reported almost complete $\mathrm{ClO}_{4}{ }^{-}$ removal in the second-stage MBfR even with the interference of $\mathrm{SO}_{4}{ }^{2-}$. However, in this work, the Se removal was less than $40 \%$ in the second-stage MBfR. The discrepancy was due to the lower kinetic properties (including growth rate and affinity for substrate) of SeRB (See the SI) compared to perchlorate reducing bacteria (See Chen et al. (2017)) as well as the aided growth of perchlorate reducing bacteria on $\mathrm{NO}_{3}{ }^{-}$(Tang et al., 2012).

\section{CONCLUSIONS}

A biofilm model integrating the simultaneous $\mathrm{NO}_{3}{ }^{-}$and $\mathrm{SeO}_{4}{ }^{2-}$ reduction processes in the $\mathrm{H}_{2}$ based MBfR was calibrated and validated using the experimental data of a reported $\mathrm{H}_{2}$-based MBfR. The model was then applied to evaluate the effects of key operating conditions on the single-stage $\mathrm{H}_{2}$-based $\mathrm{MBfR}$ and the role of reactor configuration through comparing twostage to single-stage MBfR systems. The results showed that the influent $\mathrm{SeO}_{4}{ }^{2-}$ and $\mathrm{NO}_{3}{ }^{-}$ concentrations, $\mathrm{H}_{2}$ loading and biofilm thickness significantly influenced the steady-state microbial community structure and the resulting $\mathrm{Se}$ and $\mathrm{NO}_{3}{ }^{-}$removal in the single-stage $\mathrm{H}_{2-}$ based MBfR while the influent DO concentration only played a minor role. A high $\mathrm{SeO}_{4}{ }^{2-}$ or low $\mathrm{NO}_{3}{ }^{-}$concentration in the influent (i.e., a relatively high influent $\mathrm{SeO}_{4}{ }^{2-} / \mathrm{NO}_{3}{ }^{-}$ratio such as $>0.4 \mathrm{~g} \mathrm{Se}^{-1} \mathrm{~N}$ ) favored the growth of SeRB and therefore benefited the Se removal. When operating the single-stage $\mathrm{H}_{2}$-based $\mathrm{MBfR}$ to treat $\mathrm{SeO}_{4}{ }^{2-}$ and $\mathrm{NO}_{3}{ }^{-}$simultaneously, the $\mathrm{H}_{2}$ supply should be controlled at a proper level to avoid SeRB suppression at a too low $\mathrm{H}_{2}$ loading while minimizing $\mathrm{H}_{2}$ wastage at a too high $\mathrm{H}_{2}$ loading. A thin biofilm should be avoided to ensure a protected niche for SeRB and therefore a promising Se removal. The twostage MBfR configuration offered relatively higher efficiency in removing Se and $\mathrm{NO}_{3}{ }^{-}$ 
simultaneously under the same loading condition.

\section{ACKNOWLEDGEMENT}

This work was supported by the Recruitment Program of Global Experts, the National Natural Science Foundation of China (No. 51578391) and the Program for 100 Young Talents in Tongji University (Category A).

The authors declare no conflict of interest.

Supplementary data of this work can be found in online version of the paper.

\section{REFERENCES}

Batstone, D.J., Pind, P.F., Angelidaki, I., 2003. Kinetics of thermophilic, anaerobic oxidation of straight and branched chain butyrate and valerate. Biotechnology and Bioengineering 84, 195-204.

Cannon, H.L., 1964. Geochemistry of rocks and related soils and vegetation in the Yellow Cat area, Grand County, Utah. USGPO.

Cantafio, A.W., Hagen, K.D., Lewis, G.E., Bledsoe, T.L., Nunan, K.M., Macy, J.M., 1996. Pilot-scale selenium bioremediation of San Joaquin drainage water with Thauera selenatis. Applied and Environmental Microbiology 62, 3298-3303.

Chen, X., Liu, Y., Peng, L., Ni, B.-J., 2017. Perchlorate, nitrate, and sulfate reduction in hydrogen-based membrane biofilm reactor: Model-based evaluation. Chemical Engineering Journal 316, 82-90.

Chung, J., Nerenberg, R., Rittmann, B.E., 2006. Bioreduction of Selenate Using a HydrogenBased Membrane Biofilm Reactor. Environmental Science \& Technology 40, 1664-1671. 
Di Capua, F., Papirio, S., Lens, P.N.L., Esposito, G., 2015. Chemolithotrophic denitrification in biofilm reactors. Chemical Engineering Journal 280, 643-657.

EPA, 2009. National Primary Drinking Water Regulations. EPA 816-F-09-004.

EPA, 2015. Federal Register - Effluent Limitation Guildelines and Standards for the Steam Electric Power Generating Point Source Category, U.S. Government Publishing Office, Washington, D.C.

Fellowes, J., Pattrick, R., Green, D., Dent, A., Lloyd, J., Pearce, C., 2011. Use of biogenic and abiotic elemental selenium nanospheres to sequester elemental mercury released from mercury contaminated museum specimens. Journal of Hazardous Materials 189, 660-669.

Fesharaki, P.J., Nazari, P., Shakibaie, M., Rezaie, S., Banoee, M., Abdollahi, M., Shahverdi, A.R., 2010. Biosynthesis of selenium nanoparticles using Klebsiella pneumoniae and their recovery by a simple sterilization process. Brazilian Journal of Microbiology 41, 461-466.

Ge, H., Jensen, P.D., Batstone, D.J., 2010. Pre-treatment mechanisms during thermophilicmesophilic temperature phased anaerobic digestion of primary sludge. Water Research 44, 123-130.

Gerhardt, M.B., Green, F.B., Newman, R.D., Lundquist, T.J., Tresan, R.B., Oswald, W.J., 1991. Removal of selenium using a novel algal-bacterial process. Research journal of the water pollution control federation, 799-805.

Kleerebezem, R., Van Loosdrecht, M.C.M., 2010. A Generalized Method for Thermodynamic State Analysis of Environmental Systems. Critical Reviews in Environmental Science and Technology 40, 1-54.

Knobeloch, L., Salna, B., Hogan, A., Postle, J., Anderson, H., 2000. Blue babies and nitratecontaminated well water. Environmental Health Perspectives 108, 675-678. 
Lai, C.Y., Yang, X.E., Tang, Y.N., Rittmann, B.E., Zhao, H.P., 2014. Nitrate Shaped the Selenate-Reducing Microbial Community in a Hydrogen-Based Biofilm Reactor. Environmental Science \& Technology 48, 3395-3402.

Lee, E.W., 1989. Current options in treatment of agricultural drainage wastewater. Biotreatment of agricultural wastewater. CRC Press, Boca Raton, FL, 33-45.

Lemly, A.D., 2002. Selenium Pollution Around the World, Selenium Assessment in Aquatic Ecosystems: A Guide for Hazard Evaluation and Water Quality Criteria. Springer New York, New York, pp. 3-17.

Macy, J.M., Lawson, S., DeMoll-Decker, H., 1993. Bioremediation of selenium oxyanions in San Joaquin drainage water using Thauera selenatis in a biological reactor system. Applied Microbiology and Biotechnology 40, 588-594.

Mal, J., Nancharaiah, Y., van Hullebusch, E., Lens, P., 2017. Biological removal of selenate and ammonium by activated sludge in a sequencing batch reactor. Bioresource Technology 229, 11-19.

Ni, B.J., Yuan, Z.G., 2013. A model-based assessment of nitric oxide and nitrous oxide production in membrane-aerated autotrophic nitrogen removal biofilm systems. Journal of Membrane Science 428, 163-171.

Reichert, P., 1998. AQUASIM 2.0-Computer program for the identification and simulation of aquatic systems, EAWAG, Dubendorf, Switzerland.

Rittmann, B.E., Boltz, J.P., Brockmann, D., Daigger, G.T., Morgenroth, E., Sørensen, K.H., Takács, I., van Loosdrecht, M., Vanrolleghem, P.A., 2018. A framework for good biofilm reactor modeling practice (GBRMP). Water Science and Technology 77, 1149-1164.

Squires, R.C., Groves, G.R., Johnston, W.R., 1989. Economics of selenium removal from drainage water. Journal of Irrigation and Drainage Engineering 115, 48-57. 
Tang, Y., Ontiveros- Valencia, A., Feng, L., Zhou, C., Krajmalnik- Brown, R., Rittmann, B.E., 2013. A biofilm model to understand the onset of sulfate reduction in denitrifying membrane biofilm reactors. Biotechnology and Bioengineering 110, 763-772.

Tang, Y., Zhao, H., Marcus, A.K., Krajmalnik-Brown, R., Rittmann, B.E., 2012. A SteadyState Biofilm Model for Simultaneous Reduction of Nitrate and Perchlorate, Part 1: Model Development and Numerical Solution. Environmental Science \& Technology 46, 1598-1607.

Terada, A., Lackner, S., Tsuneda, S., Smets, B.F., 2007. Redox-stratification controlled biofilm (ReSCoBi) for completely autotrophic nitrogen removal: The effect of co- versus counter-diffusion on reactor performance. Biotechnology and Bioengineering 97, 40-51.

WHO, 2011. Selenium in Drinking-water. Background document for development of WHO Guidelines for Drinking-water Quality.

Zhang, Y., Zahir, Frankenberger, W.T., 2003. Factors Affecting Reduction of Selenate to Elemental Selenium in Agricultural Drainage Water by Enterobacter taylorae. Journal of Agricultural and Food Chemistry 51, 7073-7078.

Zhao, H.-P., Ontiveros-Valencia, A., Tang, Y., Kim, B.O., Ilhan, Z.E., Krajmalnik-Brown, R., Rittmann, B., 2013. Using a Two-Stage Hydrogen-Based Membrane Biofilm Reactor (MBfR) to Achieve Complete Perchlorate Reduction in the Presence of Nitrate and Sulfate. Environmental Science \& Technology 47, 1565-1572.

\section{Table and Figure Legends}

Table 1. Stoichiometric Matrix for the Developed Model

Table 2. Overview of the Simulation Scenarios for the Reported Results 
Figure 1. Model calibration results based on the experimental data of the MBfR reported in Lai et al. (2014): (A) concentration profiles and (B) removal efficiencies.

Figure 2. Model validation results based on the experimental data of the MBfR reported in Lai et al. (2014): (A) concentration profiles and (B) removal efficiencies.

Figure 3. Model simulation results of the MBfR based on Scenario 0 in Table 2 (depth zero represents the membrane surface): (A) distribution profiles of solid species and (B) distribution profiles of dissolved species.

Figure 4. Model simulation results of the MBfR from Scenarios 1 to 5 in Table 2: (A) effect of influent $\mathrm{SeO}_{4}{ }^{2-}$ concentration; (B) effect of influent $\mathrm{NO}_{3}{ }^{-}$concentration; (C) effect of influent DO concentration; (D) effect of $\mathrm{H}_{2}$ surface loading; and (E) effect of biofilm thickness on the Se and $\mathrm{NO}_{3}^{-}$removal efficiencies, $\mathrm{H}_{2}$ utilization efficiency, and microbial community structure in the biofilm.

Figure 5. Comparison between two-stage and single-stage MBfR systems under same loading condition (Scenario 6 in Table 2): (A) microbial community structure in the first/second-stage MBfR; (B) performance of the first/second-stage MBfR; and (C) overall removal performance of two-stage and single-stage MBfR systems. 
Table 1. Stoichiometric Matrix for the Developed Model

\begin{tabular}{|c|c|c|c|c|c|c|c|c|c|c|c|c|c|c|}
\hline$i$ & Process & $\begin{array}{c}\mathbf{S}_{\mathrm{H} 2} \\
\mathbf{C O D}\end{array}$ & $\begin{array}{c}\mathbf{S}_{\mathrm{NO}} \\
\mathbf{N}\end{array}$ & $\begin{array}{c}\mathrm{S}_{\mathrm{O} 2} \\
\mathbf{O}\end{array}$ & $\begin{array}{c}\mathrm{S}_{\mathrm{SeO4}} \\
\mathbf{S e}\end{array}$ & $\underset{\mathrm{Se}}{\mathbf{S}_{\mathrm{SeO}}}$ & $\begin{array}{c}\mathbf{X}_{\mathrm{Se}} \\
\mathbf{S e}\end{array}$ & $\begin{array}{l}\mathbf{S}_{\mathrm{UAP}} \\
\mathbf{C O D}\end{array}$ & $\begin{array}{l}\mathbf{S}_{\mathrm{BAP}} \\
\mathbf{C O D}\end{array}$ & $\begin{array}{l}\mathbf{X}_{\mathrm{ADB}} \\
\mathbf{C O D}\end{array}$ & $\begin{array}{l}\mathbf{X}_{\text {SeRB }} \\
\text { COD }\end{array}$ & $\begin{array}{c}\mathbf{X}_{\mathrm{HB}} \\
\mathbf{C O D}\end{array}$ & $\begin{array}{c}\mathbf{X}_{\mathbf{I}} \\
\text { COD }\end{array}$ & $\begin{array}{l}\mathbf{X}_{\mathrm{EPS}} \\
\mathbf{C O D}\end{array}$ \\
\hline \multicolumn{15}{|c|}{$\mathrm{H}_{2}$-based autotrophic denitrifying bacteria $(A D B)$} \\
\hline 1 & Aerobic growth & $-\frac{1}{Y_{0}}$ & & $-\frac{\left(1-Y_{0}\right) k_{1}}{Y_{0}}$ & & & & $\frac{k_{2}}{Y_{0}}$ & & $k_{1}$ & & & & $\frac{k_{3}}{Y_{0}}$ \\
\hline 2 & Anoxic growth & $-\frac{1}{Y_{1}}$ & $-\frac{\left(1-Y_{1}\right) k_{1}}{2.86 Y_{1}}$ & & & & & $\frac{k_{2}}{Y_{1}}$ & & $k_{1}$ & & & & $\frac{k_{3}}{Y_{1}}$ \\
\hline 3 & Decay & & & & & & & & & -1 & & & $1-f_{d}$ & \\
\hline \multicolumn{15}{|c|}{ Selenate reducing bacteria (SeRB) } \\
\hline 4 & Aerobic growth & $-\frac{1}{Y_{0}}$ & & $-\frac{\left(1-Y_{0}\right) k_{1}}{Y_{0}}$ & & & & $\frac{k_{2}}{Y_{0}}$ & & & $k_{1}$ & & & $\frac{k_{3}}{Y_{0}}$ \\
\hline 5 & $\begin{array}{l}\text { Anoxic growth on } \\
\mathrm{SeO}_{4}^{2-} \text { reduction }\end{array}$ & $-\frac{1}{Y_{2}}$ & & & $-\frac{4.94\left(1-Y_{2}\right) k_{1}}{Y_{2}}$ & $\frac{4.94\left(1-Y_{2}\right) k_{1}}{Y_{2}}$ & & $\frac{k_{2}}{Y_{2}}$ & & & $k_{1}$ & & & $\frac{k_{3}}{Y_{2}}$ \\
\hline 6 & $\begin{array}{l}\text { Anoxic growth on } \\
\mathrm{SeO}_{3}^{2-} \text { reduction }\end{array}$ & $-\frac{1}{Y_{3}}$ & & & & $-\frac{2.47\left(1-Y_{3}\right) k_{1}}{Y_{3}}$ & $\frac{2.47\left(1-Y_{3}\right) k_{1}}{Y_{3}}$ & $\frac{k_{2}}{Y_{3}}$ & & & $k_{1}$ & & & $\frac{k_{3}}{Y_{3}}$ \\
\hline 7 & Decay & & & & & & & & & & -1 & & $1-f_{d}$ & \\
\hline \multicolumn{15}{|c|}{ Heterotrophic bacteria $(\mathrm{HB})$} \\
\hline 8 & Hydrolysis of EPS & & & & & & & & 1 & & & & & -1 \\
\hline 9 & $\begin{array}{l}\text { Aerobic growth } \\
\text { on UAP }\end{array}$ & & & $-\frac{1-Y_{4}}{Y_{4}}$ & & & & $-\frac{1}{Y_{4}}$ & & & & 1 & & \\
\hline 10 & $\begin{array}{l}\text { Aerobic growth } \\
\text { on BAP }\end{array}$ & & & $-\frac{1-Y_{5}}{Y_{5}}$ & & & & & $-\frac{1}{Y_{5}}$ & & & 1 & & \\
\hline 11 & $\begin{array}{c}\text { Anoxic growth on } \\
\text { UAP }\end{array}$ & & $-\frac{1-Y_{4}}{2.86 Y_{4}}$ & & & & & $-\frac{1}{Y_{4}}$ & & & & 1 & & \\
\hline 12 & $\begin{array}{c}\text { Anoxic growth on } \\
\text { BAP }\end{array}$ & & $-\frac{1-Y_{5}}{2.86 Y_{5}}$ & & & & & & $-\frac{1}{Y_{5}}$ & & & 1 & & \\
\hline 13 & Decay & & & & & & & & & & & -1 & $1-f_{d}$ & \\
\hline
\end{tabular}


Table 2. Overview of the Simulation Scenarios for the Reported Results

\begin{tabular}{|c|c|c|}
\hline Scenario & Simulation condition & Variable condition \\
\hline $\begin{array}{l}\text { Scenario } 0 \\
\text { Standard simulation of } \\
\text { the } \mathrm{MBfR} \text { with } \mathrm{NO}_{3}{ }^{-} \text {and } \\
\mathrm{SeO}_{4}{ }^{2-} \text { in the influent }\end{array}$ & $\begin{array}{l}S_{\mathrm{SeO} 4}=1.0 \mathrm{~g} \mathrm{Se} \mathrm{m}^{-3} \\
S_{\mathrm{NO} 3}=10.0 \mathrm{~g} \mathrm{~N} \mathrm{~m}^{-3} \\
S_{\mathrm{O} 2}=8.0 \mathrm{~g} \mathrm{~m}^{-3} \\
L_{\mathrm{In}}=0.00236 \mathrm{~m} \mathrm{~h}^{-1}(\text { i.e., } \mathrm{HRT}=3.0 \mathrm{~h}) \\
L_{\mathrm{H} 2}=0.128 \mathrm{~g} \mathrm{COD} \mathrm{m}^{-2} \mathrm{~h}^{-1} \\
L_{\mathrm{f}}=100 \mu \mathrm{m}\end{array}$ & - \\
\hline $\begin{array}{l}\text { Scenario } 1 \\
\text { Effect of influent } \mathrm{SeO}_{4}{ }^{2-} \\
\text { concentration on the } \\
\text { MBfR }\end{array}$ & $\begin{array}{l}S_{\mathrm{NO} 3}=10.0 \mathrm{~g} \mathrm{~N} \mathrm{~m}^{-3} \\
S_{\mathrm{O} 2}=8.0 \mathrm{~g} \mathrm{~m}^{-3} \\
L_{\mathrm{In}}=0.00236 \mathrm{~m} \mathrm{~h}^{-1}(\text { i.e., } \mathrm{HRT}=3.0 \mathrm{~h}) \\
L_{\mathrm{H} 2}=0.128 \mathrm{~g} \mathrm{COD} \mathrm{m}^{-2} \mathrm{~h}^{-1} \\
L_{\mathrm{f}}=100 \mu \mathrm{m}\end{array}$ & $S_{\mathrm{SeO} 4}=0.1-5.0 \mathrm{~g} \mathrm{Se} \mathrm{m}^{-3}$ \\
\hline $\begin{array}{l}\text { Scenario } 2 \\
\text { Effect of influent } \mathrm{NO}_{3}{ }^{-} \\
\text {concentration on the } \\
\text { MBfR }\end{array}$ & $\begin{array}{l}S_{\mathrm{SeO} 4}=1.0 \mathrm{~g} \mathrm{Se} \mathrm{m}^{-3} \\
S_{\mathrm{O} 2}=8.0 \mathrm{~g} \mathrm{~m}^{-3} \\
L_{\mathrm{In}}=0.00236 \mathrm{~m} \mathrm{~h}^{-1} \text { (i.e., HRT }=3.0 \mathrm{~h} \text { ) } \\
L_{\mathrm{f}}=100 \mu \mathrm{m}\end{array}$ & $S_{\mathrm{NO} 3}=0.1-15.0 \mathrm{~g} \mathrm{~N} \mathrm{~m}^{-3}$ \\
\hline $\begin{array}{l}\text { Scenario } 3 \\
\text { Effect of influent DO } \\
\text { concentration on the } \\
\text { MBfR }\end{array}$ & $\begin{array}{l}S_{\mathrm{SeO} 4}=1.0 \mathrm{~g} \mathrm{Se} \mathrm{m}^{-3} \\
S_{\mathrm{NO} 3}=10.0 \mathrm{~g} \mathrm{~N} \mathrm{~m}^{-3} \\
L_{\mathrm{In}}=0.00236 \mathrm{~m} \mathrm{~h}^{-1}(\text { i.e., } \mathrm{HRT}=3.0 \mathrm{~h}) \\
L_{\mathrm{H} 2}=0.128 \mathrm{~g} \mathrm{COD} \mathrm{m}^{-2} \mathrm{~h}^{-1} \\
L_{\mathrm{f}}=100 \mu \mathrm{m}\end{array}$ & $S_{\mathrm{O} 2}=0-8.0 \mathrm{~g} \mathrm{~m}^{-3}$ \\
\hline $\begin{array}{l}\text { Scenario } 4 \\
\text { Effect of } L_{\mathrm{H} 2} \text { on the } \\
\text { MBfR }\end{array}$ & $\begin{array}{l}S_{\mathrm{SeO} 4}=1.0 \mathrm{~g} \mathrm{Se} \mathrm{m}^{-3} \\
S_{\mathrm{NO} 3}=10.0 \mathrm{~g} \mathrm{~N} \mathrm{~m}^{-3} \\
S_{\mathrm{O} 2}=8.0 \mathrm{~g} \mathrm{~m}^{-3} \\
L_{\mathrm{In}}=0.00236 \mathrm{~m} \mathrm{~h}^{-1} \text { (i.e., HRT }=3.0 \mathrm{~h} \text { ) } \\
L_{\mathrm{f}}=100 \mu \mathrm{m}\end{array}$ & $L_{\mathrm{H} 2}=0.063-0.140 \mathrm{~g} \mathrm{COD} \mathrm{m}^{-2} \mathrm{~h}^{-1}$ \\
\hline $\begin{array}{l}\text { Scenario } 5 \\
\text { Effect of } L_{\mathrm{f}} \text { on the MBfR }\end{array}$ & $\begin{array}{l}S_{\mathrm{SeO} 4}=1.0 \mathrm{~g} \mathrm{Se} \mathrm{m}^{-3} \\
S_{\mathrm{NO} 3}=10.0 \mathrm{~g} \mathrm{~N} \mathrm{~m}^{-3} \\
S_{\mathrm{O} 2}=8.0 \mathrm{~g} \mathrm{~m}^{-3} \\
L_{\mathrm{In}}=0.00236 \mathrm{~m} \mathrm{~h}^{-1}(\text { i.e., } \mathrm{HRT}=3.0 \mathrm{~h}) \\
L_{\mathrm{H} 2}=0.128 \mathrm{~g} \mathrm{COD} \mathrm{m}^{-2} \mathrm{~h}^{-1}\end{array}$ & $L_{\mathrm{f}}=40-180 \mu \mathrm{m}$ \\
\hline $\begin{array}{l}\text { Scenario } 6 \\
\text { Comparison between } \\
\text { two-stage and single- } \\
\text { stage MBfR systems } \\
\text { under same loading } \\
\text { condition }\end{array}$ & $\begin{array}{l}S_{\mathrm{SeO} 4}=1.0 \mathrm{~g} \mathrm{Se} \mathrm{m}^{-3} \\
S_{\mathrm{NO} 3}=10.0 \mathrm{~g} \mathrm{~N} \mathrm{~m}^{-3} \\
S_{\mathrm{O} 2}=8.0 \mathrm{~g} \mathrm{~m}^{-3} \\
\left.L_{\mathrm{In}}=0.00118 \mathrm{~m} \mathrm{~h}^{-1} \text { (i.e., } \mathrm{HRT}=6.0 \mathrm{~h}\right)\end{array}$ & $\begin{array}{l}L_{\mathrm{f}}=100 \mu \mathrm{m} \text { for single-stage } \\
\text { MBfR system } \\
L_{\mathrm{f}}=100 / 40 \mu \mathrm{m} \text { for first/second- } \\
\text { stage MBfR of the two-stage } \\
\text { system }\end{array}$ \\
\hline
\end{tabular}


$\mathrm{SeO}_{4}{ }^{2-}: \quad$ influent $\longrightarrow$ model $\square$ effluent $\mathrm{SeO}_{3}{ }^{2-}:-$ model $\triangle$ effluent $\mathrm{NO}_{3}^{-}:$influent $\longrightarrow$ model $\bigcirc$ effluent
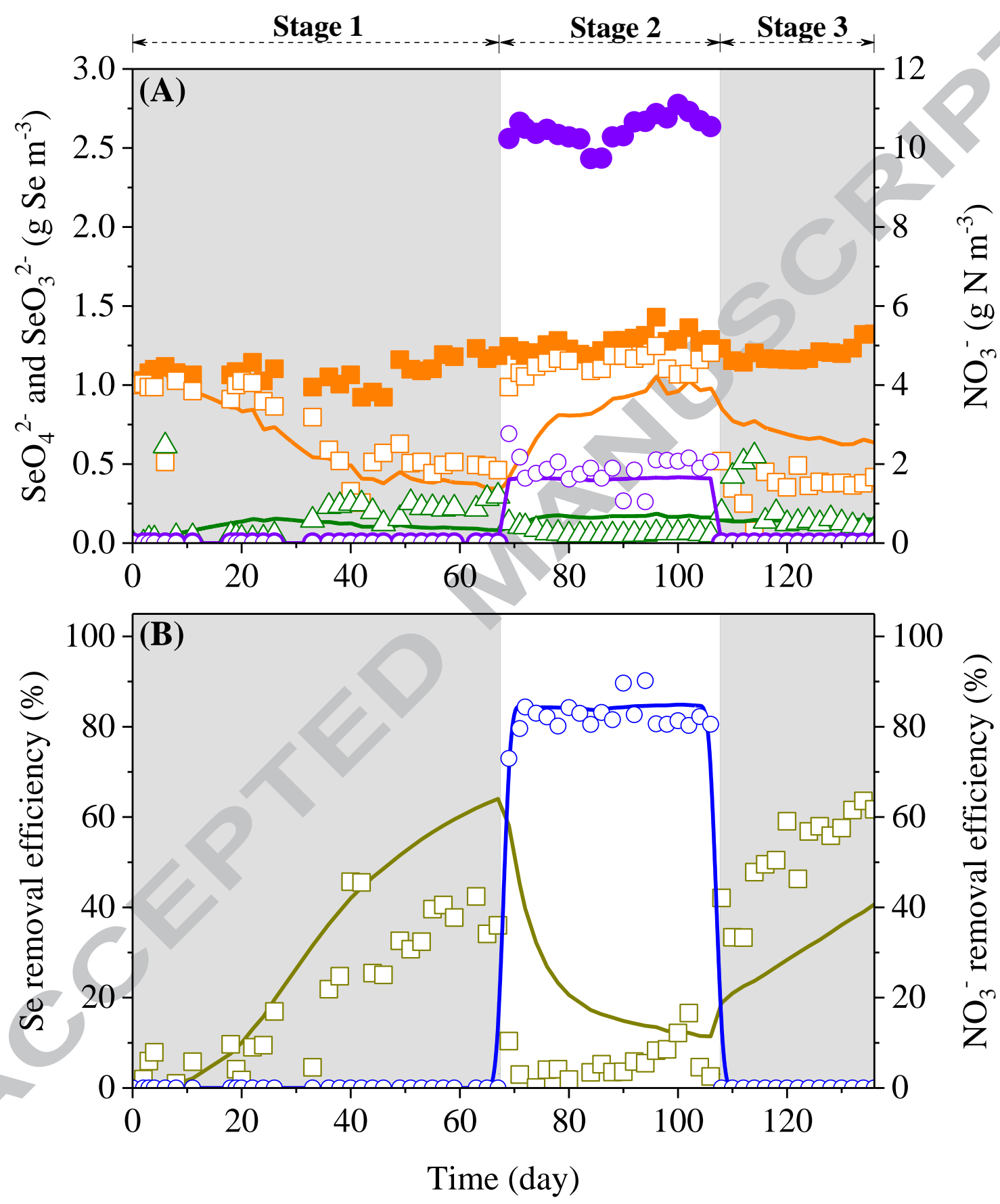

Se removal: $\longrightarrow$ model $\square$ experiment $\quad \mathrm{NO}_{3}{ }^{-}$removal: $\longrightarrow$ model $\bigcirc$ experiment

Figure 1. Model calibration results based on the experimental data of the MBfR reported in Lai et al. (2014): (A) concentration profiles and (B) removal efficiencies. 
$\mathrm{SeO}_{4}{ }^{2-}: \quad$ influent $\longrightarrow$ model $\square$ effluent $\mathrm{SeO}_{3}{ }^{2-}:-$ model $\triangle$ effluent $\mathrm{NO}_{3}^{-}:$influent $\longrightarrow$ model $\bigcirc$ effluent
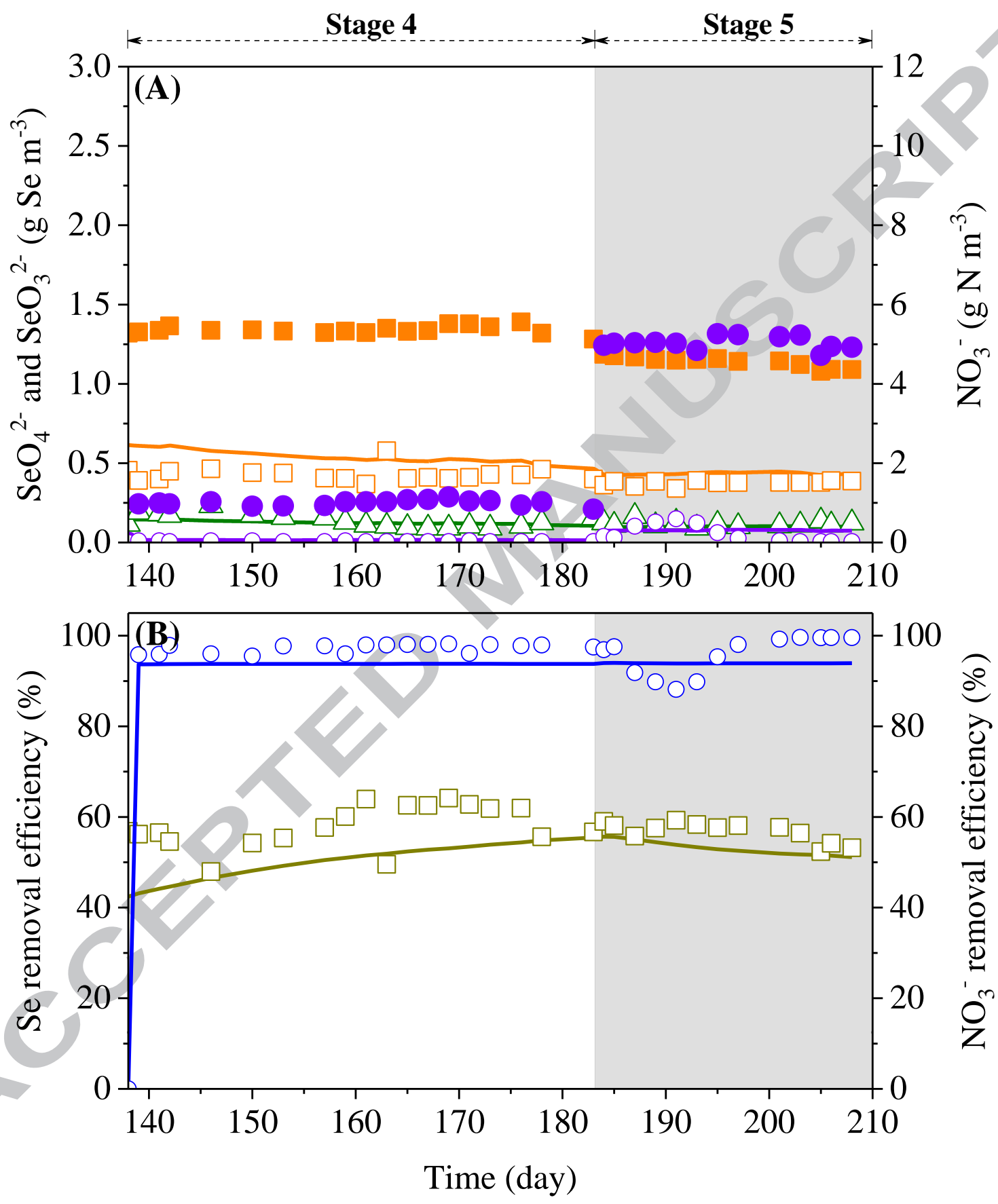

Se removal: $\square$ model $\square$ experiment $\quad \mathrm{NO}_{3}{ }^{-}$removal: $\longrightarrow$ model $\bigcirc$ experiment

Figure 2. Model validation results based on the experimental data of the MBfR reported in Lai et al. (2014): (A) concentration profiles and (B) removal efficiencies. 

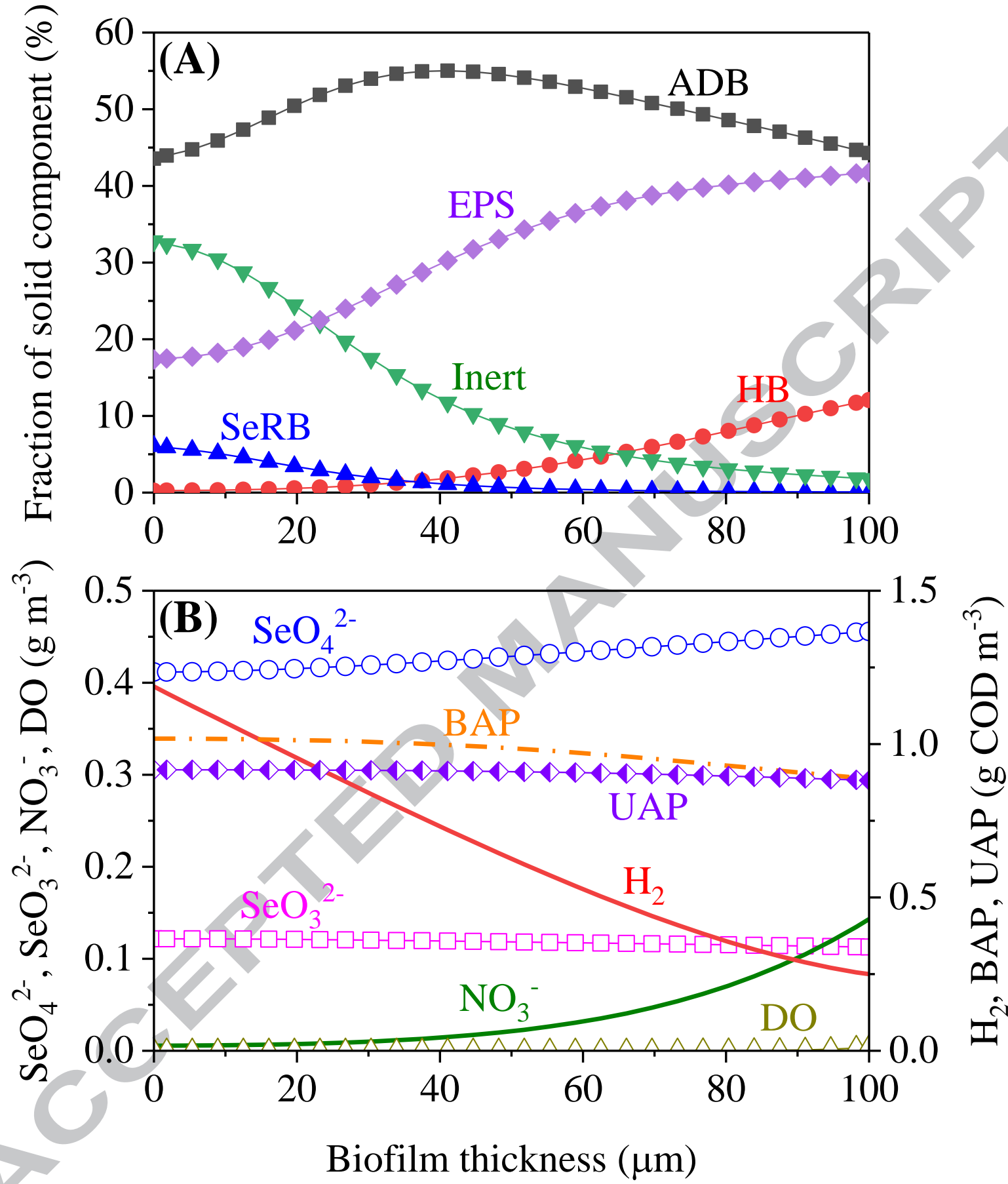

Figure 3. Model simulation results of the MBfR based on Scenario 0 in Table 2 (depth zero represents the membrane surface): (A) distribution profiles of solid species and (B) distribution profiles of dissolved species. 
(A)

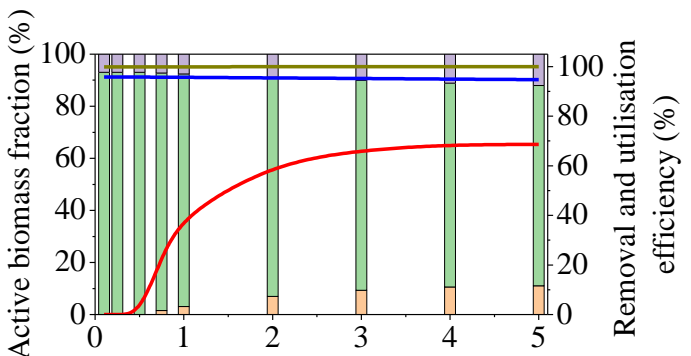

(C)

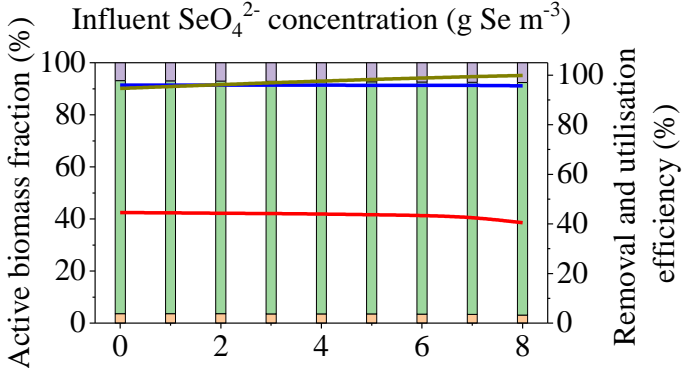

(E)

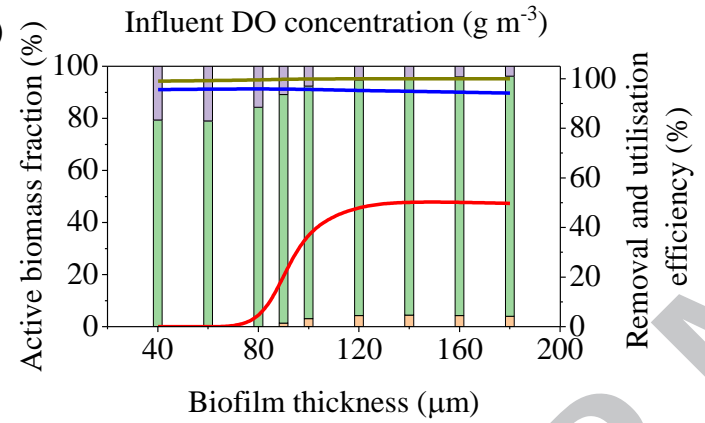

(B)

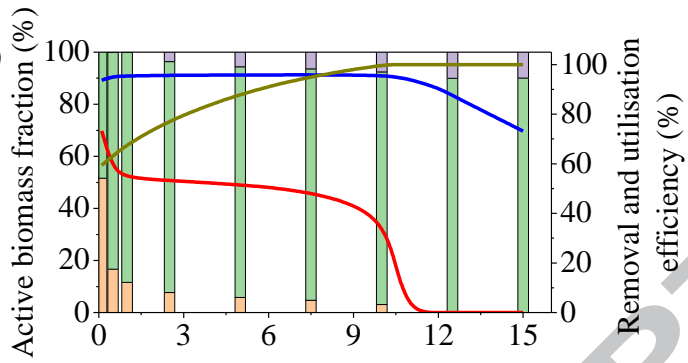

(D) $\widehat{\&}$ Influent $\mathrm{NO}_{3}^{-}$concentration $\left(\mathrm{g} \mathrm{N} \mathrm{m}^{-3}\right)$

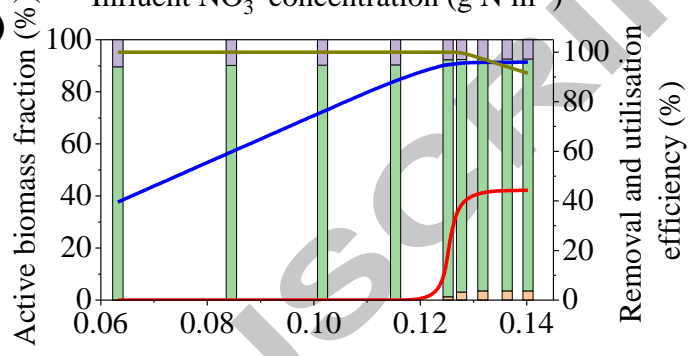

$\mathrm{H}_{2}$ loading $\left(\mathrm{g} \mathrm{COD} \mathrm{m}^{-2} \mathrm{~h}^{-1}\right)$

\section{Legends:}

SeRB $\quad$ Se removal

$\mathrm{ADB}-\mathrm{NO}_{3}^{-}$removal

$\mathrm{HB}-\mathrm{H}_{2}$ utilisation

Figure 4. Model simulation results of the MBfR from Scenarios 1 to 5 in Table 2: (A) effect of influent $\mathrm{SeO}_{4}{ }^{2-}$ concentration; (B) effect of influent $\mathrm{NO}_{3}{ }^{-}$concentration; (C) effect of influent DO concentration; (D) effect of $\mathrm{H}_{2}$ surface loading; and (E) effect of biofilm thickness on the $\mathrm{Se}$ and $\mathrm{NO}_{3}{ }^{-}$removal efficiencies, $\mathrm{H}_{2}$ utilization efficiency, and microbial community structure in the biofilm. 


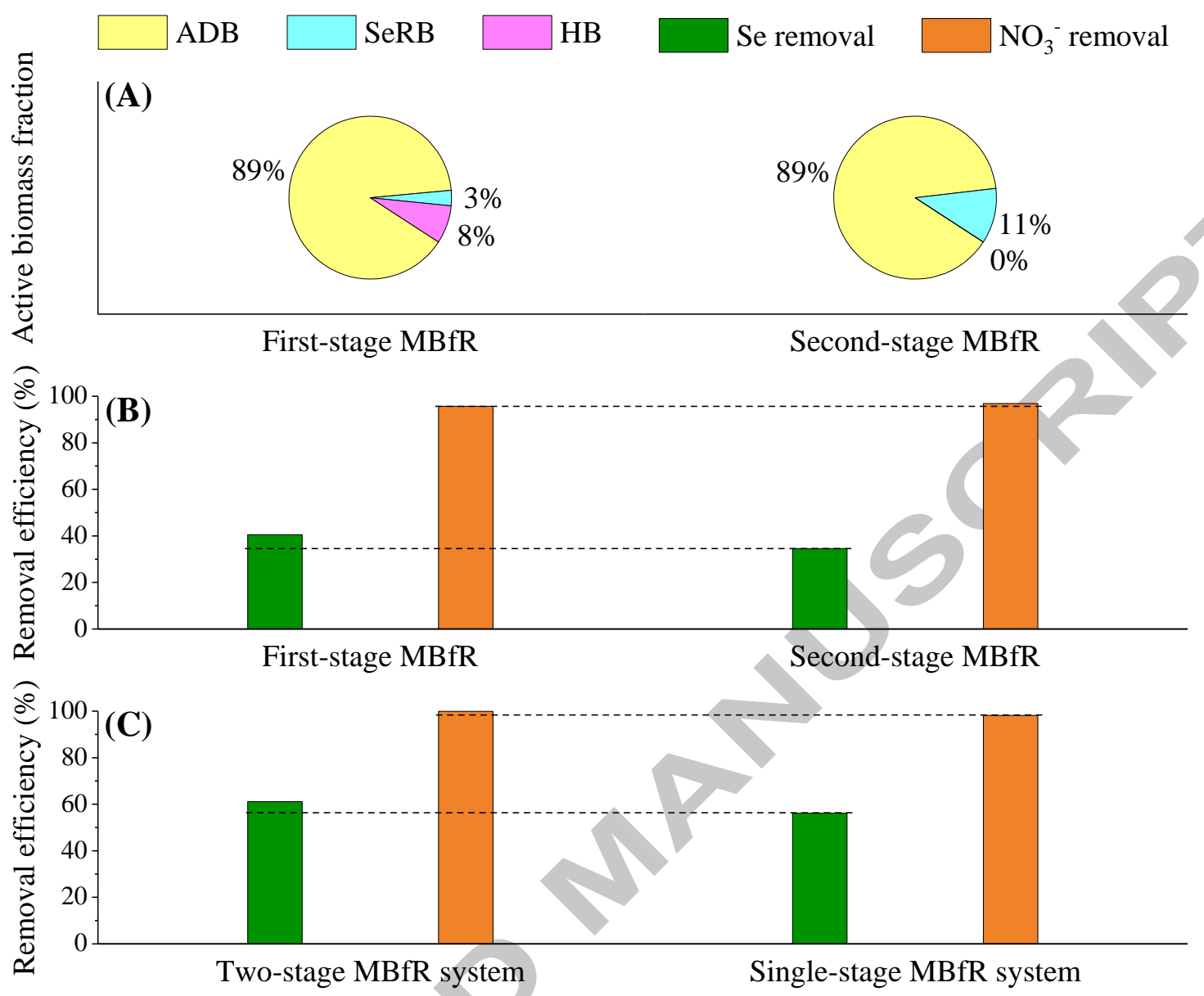

Figure 5. Comparison between two-stage and single-stage MBfR systems under same loading condition (Scenario 6 in Table 2): (A) microbial community structure in the first/second-stage MBfR; (B) performance of the first/second-stage MBfR; and (C) overall removal performance of two-stage and single-stage MBfR systems. 


\section{Highlights}

A model was developed to describe $\mathrm{SeO}_{4}{ }^{2-}$ and $\mathrm{NO}_{3}{ }^{-}$reduction in $\mathrm{H}_{2}$-based MBfR. A high influent $\mathrm{SeO}_{4}{ }^{2-} / \mathrm{NO}_{3}{ }^{-}$ratio and a thick biofilm thickness favored Se removal. Moderate $\mathrm{H}_{2}$ supply avoided SeRB suppression whilst minimizing $\mathrm{H}_{2}$ wastage.

Two-stage MBfR had a slightly better removal performance than single-stage MBfR. 


\section{Graphical Abstract}

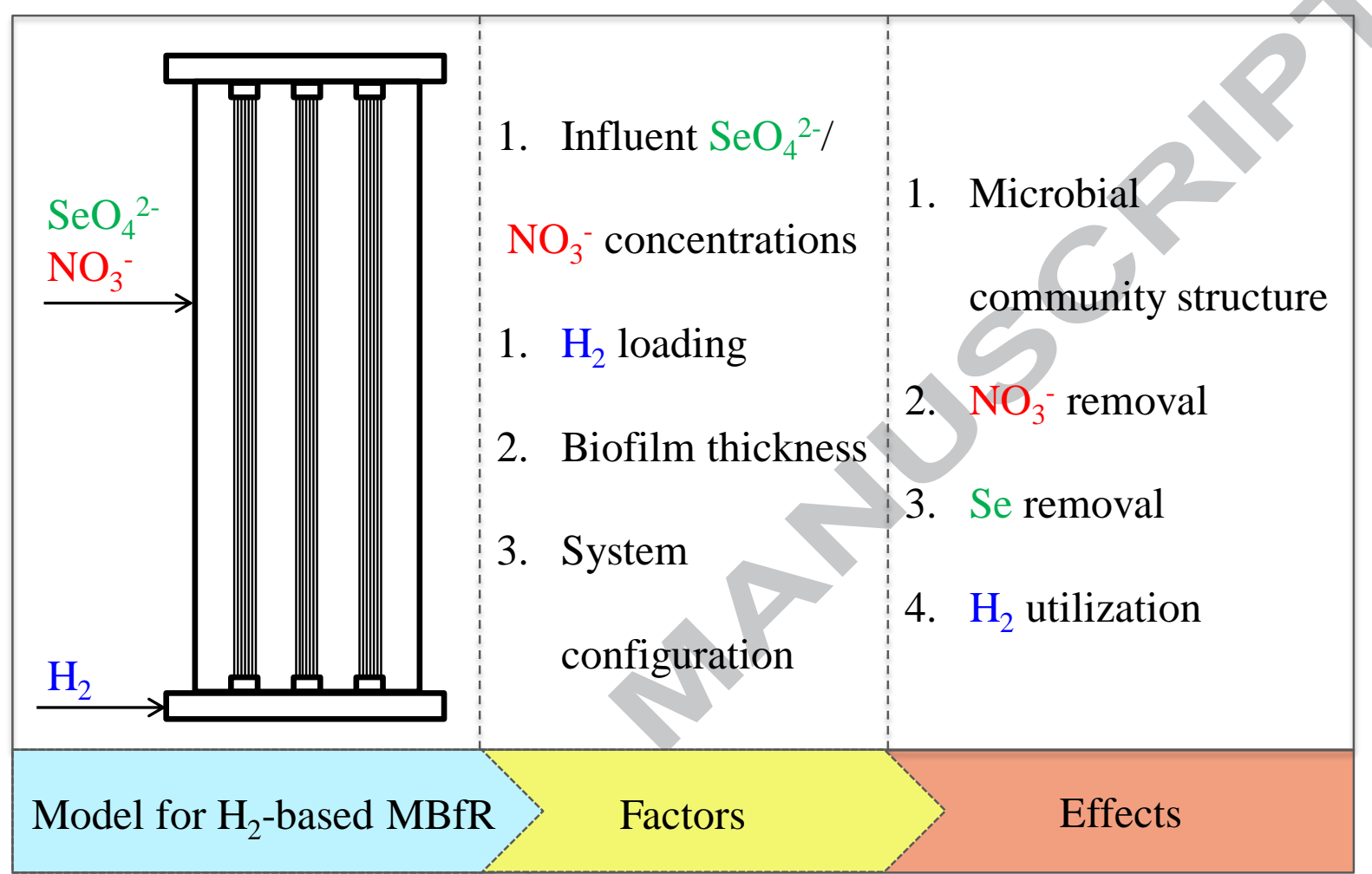

